\title{
IMMEDIATE RADIATION EFFECTS AND DETERMINATION OF OPTIMAL DOSE OF GAMMA RAYS ON NON-BASMATI AROMATIC RICE (Oryza Sativa L.) OF EASTERN INDIA
}

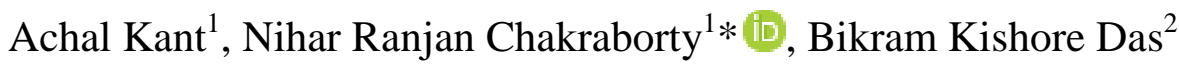 \\ ${ }^{1}$ Department of Genetics and Plant Breeding, Institute of Agriculture, Visva-Bharati University, Sriniketan-731236, West Bengal, India \\ ${ }^{2}$ Nuclear Agriculture and Biotechnology Division, Bhabha Atomic Research Centre (BARC), Mumbai-400085, Maharashtra, India \\ Received - June 25, 2020; Revision - September 22, 2020; Accepted - October 15, 2020 \\ Available Online - October 25, 2020
}

DOI: http://dx.doi.org/10.18006/2020.8(5).586.604

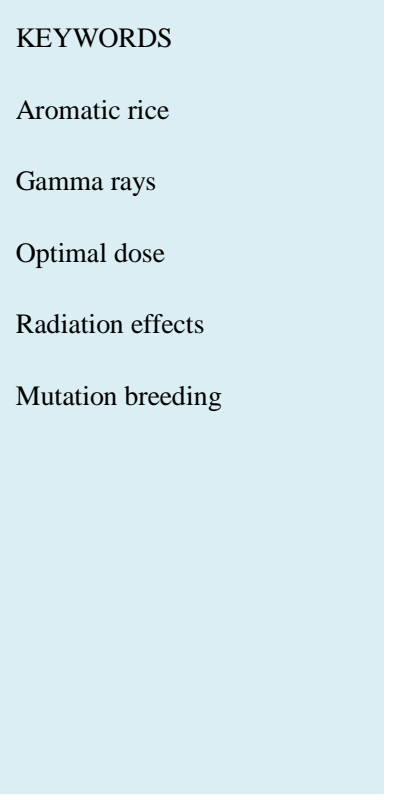

\begin{abstract}
Non-basmati aromatic rice is very popular for its excellent grain quality with an inbuilt aroma. But these cultivars have been ignored in the mainstream industrial agriculture due to low yielder. It is a serious matter that most of these cultivars are fast disappearing from cultivation in the locality. Therefore, there is an urgent need to improve these cultivars. Mutation breeding is one of the options to improve/rectify of specific traits of these cultivars within a very short period without altering the in-built quality traits viz. aroma. The prime objectives of the experiment were to determine radiation effects and to estimate the optimal dose which was necessary for any mutagenesis-based breeding programme. Popular cultivars namely Badshabhog, Bahadurbhog and Blackjoha were taken for gamma irradiation ranging from 200Gy to 400Gy with an interval of 50Gy and unexposed treatment used as control. The experiment was designed at in vitro and in vivo condition in a randomized block design with three replications. Data were analyzed through Duncan's test and regression analysis. Most of the traits of each cultivar were exhibited a drastic reduction with increasing doses of gamma rays. The optimal dose of gamma rays based on the weighted mean of $\mathrm{LD}_{50}$ and $\mathrm{GR}_{30} / \mathrm{GR}_{50}$ with $40 \%$ and $10 \%$ weighted, respectively under in vitro and in vivo conditions were estimated at 358.37Gy \& 346.10Gy in Badshabhog; 331.19Gy \& 319.17Gy in Bahadurbhog; 314.55Gy \& 314.05Gy in Blackjoha. This optimum dose of gamma rays can be used for obtaining desirable mutants of these cultivars with minimal damages. Blackjoha had the highest radiosensitivity while Badshabhog showed relatively tolerant.
\end{abstract}

* Corresponding author

E-mail: nrchakraborty@gmail.com (Dr. Nihar Ranjan Chakraborty)

Peer review under responsibility of Journal of Experimental Biology and Agricultural Sciences.

Production and Hosting by Horizon Publisher India [HPI] (http://www.horizonpublisherindia.in/).

All rights reserved.
All the articles published by Journal of Experimental Biology and Agricultural Sciences are licensed under a Creative Commons Attribution-NonCommercial 4.0 International License Based on a work at www.jebas.org.

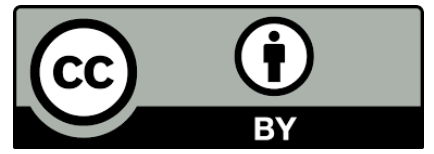




\section{Introduction}

Aromatic rice is a small and special group of rice which is known for its fragrance and best in quality. It is more popular or demandable in Middle-East, European counties, and the United States. The dominant aromatic rice in world trade is 'Basmati' which grown in north-western India e.g. Punjab, Haryana, Uttarakhand, Himachal Pradesh, Delhi, Western U.P., and Pakistan (Hameed et al., 2020). Basmati rice production is not satisfactory in eastern India like West Bengal, eastern U.P., Jharkhand and Odisha due to non- retention of its original aroma, difficulty in milling because of very poor head rice recovery and also high susceptibility to insects-pests (Chakraborty \& Kole, 2014). However, some aromatic landraces such as Badshabhog, Gobindabhog, Blackjoha, Bahadurbhog, Radhunipagol, Seetabhog, Tulaipanja etc., are very popular in eastern India due to its excellent grain quality, aroma and specific cooking quality features but they are not recognized as 'Basmati' rice due to their small to medium grain size (Chakraborty \& Kole, 2014). These cultivars have some undesirable traits such as lodging susceptibility due to higher plant height $(156-174 \mathrm{~cm}$.) along with the less sturdy stem, high maturity duration (150-178 days) and blast susceptibility in the fluctuating environment caused yield reduction (Chakravarti et al., 2012). Therefore, there is an urgent need to improve the yield potential of such types of non-basmati aromatic rice without disrupting its original grain quality and cooking quality features. Genetic improvement in specific traits like the height of the plant, duration of maturity, yield and its component characters through hybridization and recombination often becomes difficult due to break-down of aroma and cooking quality characters. Mutation breeding is one of the options to improve/rectify specific traits of these cultivars within a very short period without break-down of in-built quality traits.

Mutation induction offers for generating genetic variability, which may allow to identification of new desired attributes that either cannot be found in nature or have been lost during evolution (Oladosu et al., 2016). The most important aspects of mutation breeding have been the induction of polygenic mutation which can increase yield as well as other important agronomic characters (Abdelnour-Esquivel et al., 2020; Mamun et al., 2020). Globally, the 3,329 crop mutant cultivars including 513 mutant rice varieties obtaining by gamma irradiation were officially registered in FAO/IAEA mutant variety database (MVD, 2020). Since the 1960s, gamma rays have been most frequently used by the breeders in plant mutation breeding programme. Because gamma rays are considered as the most penetrating electromagnetic radiation and its operation is simpler from the other physical mutagens (Kovacs \& Keresztesa, 2002; Li et al., 2019).

Generally, Radio-sensitivity of the crops is varied and depending on the species, the varieties, plant part of the mutation and the water content of the material (Spencer-Lopes et al., 2018). Free radicals, can modify or damage important components of plant cells, are produced on the interaction with molecules in the plant cells, particularly water (Gowthami et al., 2017). One group of researchers agrees that the maximum probability to generate effective mutations founds at a dose where $50 \%$ of the irradiated individuals die (Ángeles-Espino et al., 2013). While other scientists have pointed out that another dose with the highest probability of producing beneficial mutations, abreast of $\mathrm{LD}_{50}$, is where $30 \%$ or $50 \%$ of a growth reduction $\left(\mathrm{GR}_{30} / \mathrm{GR}_{50}\right)$ finds (Khalil et al., 2014).

The optimal radiation dose for crop improvement programs is determined by using the $\mathrm{LD}_{50}$ and the $\mathrm{GR}_{30} / \mathrm{GR}_{50}$ to induce effective mutations with minimal impact on the genome, while with high doses, the genome may bear multiple impacts that regularly produce aberrations or negative changes(Thole et al., 2012). Furthermore, low irradiation doses may induce cell division and enzymatic activity or increase the number of photosynthetic pigments (Aparna et al., 2013), whereas, high irradiation doses may hamper enzyme and hormonal activities that may cause physical damage to the organelles or chemical changes in the cells (Alvarez-Holguin et al., 2019). These types of response were not related to genetic modifications, they will not acquire. In this perception, low and high irradiation doses may cause plant phenotypic changes that may be misguided for genetic changes (Alvarez-Holguin et al., 2019). Therefore, the optimal radiation dose must be determined before starting a mutagenesis-based genetic improvement programme; this will increase the possibility of finding effective mutations that help to avoid excessive losses in terms of time, cost of manpower, field area and experimental materials. The present investigation was undertaken to conduct a gamma rays sensitivity test for biological and quantitative traits and determination of optimal radiation dose in non-basmati aromatic rice Badshabhog, Bahadurbhog, and Blackjoha.

\section{Materials and Methods}

\subsection{Plant materials and mutagen treatment}

Three non-basmati aromatic cultivars of rice namely Badshabhog (whitish creamy, short-medium cylinder seeds, maturity 150160days), Bahadurbhog (brownish, short cylinder grain, maturity 155-165 days), Blackjoha (blackish, medium cylinder grain with an awn, maturity 140-150 days) were collected from Rice Research Station Chinsurah, Hooghly, West Bengal, India for radiation treatment. Genetically uniform, disease free, healthy seeds with 12 percent moisture of three cultivars each weighing $100 \mathrm{~g}$ were taken in six packets for the experiment. Five such packets of each cultivar were used for gamma irradiations. The seeds were placed inside the gamma radiation chamber to get the seeds irradiated with five different doses of gamma rays viz. 200Gy, 250Gy, 
300Gy, 350Gy, and 400Gy from the Cobalt 60 gamma rays source for the appropriate time for each dose based on the half-life of the source at BARC, Trombay, Mumbai in India. The dose rate was of the order of $17 \mathrm{~Gy} / \mathrm{min}$ in the radiation chamber. Sixth unexposed seed packet was used as control.

\subsection{Experimental design, Growing plants, Data collection, and Statistical analysis}

The experiments were carried out at the Department of Genetics and Plant Breeding (in vitro experiment) and Agriculture farm (in vivo experiment) of Palli Shikha Bhavana (Institute of Agriculture), Visva-Bharati, Sriniketan, West Bengal, India. Both experiments were organized in a completely randomized block design with three replications. Under in vitro condition, 50 irradiated seeds (Spencer-Lopes et al., 2018) of each dose of three cultivars along with their control were grown on vertically stand blotting papers.

Another experiment was carried out under in vivo conditions. The remaining seeds of each dose with their control were sown in raised nursery beds in the field at the same time. All necessary nursery practices were applied from time to time. Twenty-five days old seedlings of all three cultivars of each dose along with control were transplanted into the main field by adopting intra-row spacing of $15 \mathrm{~cm}$ with a single seedling per hill and $20 \mathrm{~cm}$ row to row spacing in completely randomized block design with three replications. The recommended dose of N P K fertilizer and standard cultural practices were carried out for better crop growth.

The number of germinated seeds when both plumule and radicle were fully emerged counted for a period at $7^{\text {th }}$ DAS (days after sowing) under both in vitro and in vivo condition (Lalitha et al., 2019) and expressed in percentage. Shoot length and root length were measured at $14^{\text {th }}$ DAS when the first true leaves in control seedlings of each cultivar have been stopped growing as well as the second leaf just to initiate. The measurement was taken on randomly selected seedling in centimeters from the root-shoot junction (under in vitro) or soil level (under in vivo) up to the tip of the first leaf for the shoot. Seedling height $(\mathrm{cm})$ under in vivo was taken on randomly selected seedlings (completed three leaves stage) in centimeters at $25^{\text {th }}$ DAS (just before transplanting into the main field). Seedling survival percent as counted at $14^{\text {th }}$ and $25^{\text {th }}$ DAS (just before transplanting into the main field) under both in vitro and in vivo condition respectively and expressed in percentage. Data on various quantitative traits were also recorded on ten randomly selected plants in the main field.

Data were subjected to the standard analysis both in vitro and in vivo conditions and determination of $\mathrm{LD}_{50}$ as well as $\mathrm{GR}_{30} / \mathrm{GR}_{50}$ doses of gamma rays using Microsoft excel 2016. The comparison between treatment means was tested for biological and quantitative traits with Duncan's test (Duncan, 1955) by using IBM SPSS Statistics 25.

Determination of the lethal dose $\left(\mathrm{LD}_{50}\right)$ of gamma rays for germination of seeds and seedling survival under in vitro as well as in vivo conditions was carried out through Probit analysis (Finney, 1971; Gowthami et al., 2017). Probit mortality values for each genotype were plotted on the $y$-axis in a graph against to the $\log 10$ doses on the $\mathrm{x}$-axis through linear regression line by fitting linear regression equation, $y=m x+c$ (where $y$ is response variable, $x$ is the irradiated $\log$ dose) was used to estimate the $\log 10$ dose associated with a probit of 5. Antilog of the $\log 10$ value corresponding to the probit 5 was taken to find out the $\mathrm{LD}_{50}$ value of gamma rays for the particular trait under study.

Percentage over control \{(Mean of irradiated treatment/mean of control treatment) $\times 100\}$ and percentage reduction (100percentage over control)(Spencer-Lopes et al., 2018) were applied to determine the percent growth reduction ( $\% \mathrm{GR})$ of the seedling growth parameters to gamma rays. Straight line equation $\mathrm{y}=$ $\mathrm{mx}+\mathrm{c}$ (where $\mathrm{y}$ is percentage reduction values, $\mathrm{x}$ is the irradiated dose) were used to estimate the $\mathrm{GR}_{30}$ and $\mathrm{GR}_{50}$ dose of gamma rays associated with $30 \%$ and $50 \%$ growth reduction, respectively in traits under study.

Under in vitro condition, a weighted mean for each cultivar was calculated based on the results of the $\mathrm{LD}_{50}$ obtained for germination (\%) and seedling survival (\%); $\mathrm{GR}_{30}$ and $\mathrm{GR}_{50}$ were obtained from shoot length and root length, respectively. Whereas under in vivo condition, a weighted mean for each cultivar was estimated based on the results of $\mathrm{LD}_{50}$ obtained for germination $(\%)$ and seedling survival (\%); $\mathrm{GR}_{30}$ obtained for shoot length and seedling height. The $\mathrm{LD}_{50}$ was weighted with $40 \%$ for germination $(\%)$ and seedling survival (\%), and the $\mathrm{GR}_{30} / \mathrm{GR}_{50}$, with $10 \%$ for remaining traits (shoot length, root length, and seedling height). The germination (\%) and seedling survival (\%) were the variables to which the highest weighting (40\% for each) was assigned because the death of the individual indicates the highest damage that gamma radiation can produce. A single value under in vitro and in vivo condition was thus obtained, whereby the optimal radiation dose of gamma radiation for inducing mutagenesis in Badshabhog, Bahadurbhog, and Blackjoharice were established.

\section{Results}

\subsection{Effects of gamma rays on various growth traits}

Table 1 showed significant differences at the 0.01 level of probability due to gamma irradiation in all three cultivars on various growth traits. Under in vitro and in vivo conditions at the period of $7^{\text {th }}$ DAS, germination percentage decreased drastically in all three cultivars with increase gamma doses. All treatments mean were 


\begin{tabular}{|c|c|c|c|c|c|c|c|c|}
\hline \multirow{2}{*}{ Treatments } & \multicolumn{2}{|c|}{ Germination (\%) } & \multicolumn{2}{|c|}{ Shoot length (cm.) } & \multirow{2}{*}{$\begin{array}{l}\text { Root length } \\
\text { (cm.) } \\
\text { (In vitro) }\end{array}$} & \multicolumn{2}{|c|}{ Seedling survival (\%) } & \multirow{2}{*}{$\begin{array}{c}\text { Seedling height } \\
\text { (cm.) } \\
\text { (Invivo) }\end{array}$} \\
\hline & In vitro & In vivo & In vitro & In vivo & & In vitro & In vivo & \\
\hline \multicolumn{9}{|c|}{ Badshabhog } \\
\hline Control & $97 \mathrm{a}$ & $93.14 \mathrm{a}$ & $7.97 \mathrm{a}$ & $13.4 \mathrm{a}$ & $16.02 \mathrm{a}$ & $95 \mathrm{a}$ & $91.00 \mathrm{a}$ & $21.01 \mathrm{a}$ \\
\hline 200Gy & $91 b$ & $83.79 b$ & $6.93 \mathrm{ab}$ & $11.8 \mathrm{~b}$ & $9.44 b$ & $85 b$ & $80.21 b$ & $19.36 \mathrm{a}$ \\
\hline 250Gy & $83 \mathrm{c}$ & $73.86 \mathrm{c}$ & $6.29 \mathrm{bc}$ & $9.61 \mathrm{c}$ & $9.03 b$ & $78 \mathrm{c}$ & $71.00 \mathrm{c}$ & $18.73 \mathrm{ab}$ \\
\hline 300Gy & $80 \mathrm{c}$ & $68.50 \mathrm{c}$ & $5.58 \mathrm{bc}$ & $8.51 \mathrm{~cd}$ & $8.17 \mathrm{~b}$ & $69 \mathrm{~d}$ & $64.93 \mathrm{~d}$ & $16.52 b c$ \\
\hline 350Gy & $59 \mathrm{~d}$ & $48.36 \mathrm{~d}$ & $4.91 \mathrm{~cd}$ & $7.68 \mathrm{~d}$ & $5.38 \mathrm{c}$ & $49 \mathrm{e}$ & $44.79 \mathrm{e}$ & $14.97 \mathrm{c}$ \\
\hline 400Gy & $39 \mathrm{e}$ & $36.00 \mathrm{e}$ & $3.61 \mathrm{~d}$ & $4.54 \mathrm{e}$ & $4.33 c$ & $37 \mathrm{f}$ & $30.93 \mathrm{f}$ & $10.79 \mathrm{~d}$ \\
\hline Mean & 74.83 & 67.27 & 5.88 & 9.26 & 8.73 & 68.83 & 63.81 & 16.90 \\
\hline S.Em & 1.83 & 1.81 & 0.46 & 0.38 & 0.79 & 1.33 & 1.84 & 0.75 \\
\hline $\mathrm{CV}$ & 3.47 & 3.80 & 10.95 & 5.82 & 12.87 & 2.73 & 4.07 & 6.30 \\
\hline \multicolumn{9}{|c|}{ Bahadurbhog } \\
\hline Control & $97 \mathrm{a}$ & $92.21 \mathrm{a}$ & $8.32 \mathrm{a}$ & $10.94 \mathrm{a}$ & $15.07 \mathrm{a}$ & $94 \mathrm{a}$ & $90.43 \mathrm{a}$ & $23.43 \mathrm{a}$ \\
\hline 200Gy & $84 b$ & $80.21 b$ & $6.81 b$ & $9.94 \mathrm{ab}$ & $11.66 \mathrm{~b}$ & $81 b$ & $77.64 b$ & $20.31 b$ \\
\hline 250Gy & $75 c$ & $64.36 \mathrm{c}$ & $6.21 b c$ & $9.01 \mathrm{~b}$ & $8.68 \mathrm{c}$ & $71 \mathrm{c}$ & $61.00 \mathrm{c}$ & $19.01 b c$ \\
\hline 300Gy & $59 \mathrm{~d}$ & $50.21 \mathrm{~d}$ & $5.69 \mathrm{c}$ & $8.85 b$ & $8.02 \mathrm{~cd}$ & $53 \mathrm{~d}$ & $45.93 \mathrm{~d}$ & $18.66 \mathrm{c}$ \\
\hline 350Gy & $47 \mathrm{e}$ & $39.29 \mathrm{e}$ & $5.43 \mathrm{c}$ & $7.06 \mathrm{c}$ & $5.80 \mathrm{de}$ & $41 \mathrm{e}$ & $34.29 \mathrm{e}$ & $17.65 \mathrm{c}$ \\
\hline 400Gy & $37 \mathrm{f}$ & $33.93 \mathrm{e}$ & $3.85 \mathrm{~d}$ & $4.96 \mathrm{~d}$ & $4.51 \mathrm{e}$ & $35 \mathrm{f}$ & $28.93 \mathrm{f}$ & $10.87 \mathrm{~d}$ \\
\hline Mean & 66.50 & 60.04 & 6.05 & 8.46 & 8.96 & 62.50 & 56.37 & 18.32 \\
\hline S.Em & 1.76 & 1.73 & 0.25 & 0.38 & 0.70 & 1.33 & 1.68 & 0.42 \\
\hline $\mathrm{CV}$ & 3.74 & 4.06 & 5.83 & 6.35 & 11.12 & 3.01 & 4.20 & 3.22 \\
\hline \multicolumn{9}{|c|}{ Blackjoha } \\
\hline Control & $93 \mathrm{a}$ & $89.14 \mathrm{a}$ & $9.09 \mathrm{a}$ & $12.53 \mathrm{a}$ & $19.24 \mathrm{a}$ & $91 \mathrm{a}$ & $85.93 \mathrm{a}$ & $24.27 \mathrm{a}$ \\
\hline 200Gy & $81 b$ & $73.57 b$ & 7.89ab & $10.39 b$ & $9.82 \mathrm{~b}$ & $78 \mathrm{~b}$ & $70.71 b$ & $20.81 b$ \\
\hline 250Gy & $71 \mathrm{c}$ & $60.79 c$ & $7.24 b c$ & $9.5 \mathrm{~b}$ & $8.85 b$ & $64 c$ & $56.50 \mathrm{c}$ & $20.33 b$ \\
\hline 300Gy & $52 \mathrm{~d}$ & $49.29 \mathrm{~d}$ & $6.11 \mathrm{~cd}$ & $7.63 \mathrm{c}$ & $8.40 \mathrm{~b}$ & $50 \mathrm{~d}$ & $46.79 \mathrm{~d}$ & $19.99 \mathrm{~b}$ \\
\hline 350Gy & $42 \mathrm{e}$ & $34.43 \mathrm{e}$ & $5.96 \mathrm{~cd}$ & $6.72 \mathrm{c}$ & $6.33 c$ & $37 \mathrm{e}$ & $29.79 \mathrm{e}$ & $17.74 \mathrm{c}$ \\
\hline 400Gy & $32 \mathrm{f}$ & $32.07 \mathrm{e}$ & $4.95 \mathrm{~d}$ & $4.94 d$ & $5.21 \mathrm{c}$ & $32 \mathrm{e}$ & $26.64 \mathrm{e}$ & $15.32 \mathrm{~d}$ \\
\hline Mean & 61.83 & 56.55 & 6.87 & 8.62 & 9.64 & 58.67 & 52.73 & 19.74 \\
\hline S.Em & 2.14 & 1.50 & 0.41 & 0.52 & 0.54 & 1.86 & 1.46 & 0.57 \\
\hline $\mathrm{CV}$ & 4.89 & 3.74 & 8.47 & 8.54 & 7.85 & 4.49 & 3.91 & 4.07 \\
\hline
\end{tabular}

All biological traits under studied were exhibited significant differences (F- Test) at the 0.01 level of probability; S.Em: Standard error due to mean; CV: Coefficient of variation.

exhibited a linear trend as per Duncan's test, except irradiation at 250Gy \& 300Gy under both conditions in Badshabhog @ 350Gy\& $400 \mathrm{~Gy}$ under in vivo condition in Bahadurbhog and Blackjoha where the response was statistically at par.

Shoot length under in vitro and in vivo condition and root length under in vivo condition of all three cultivars at $14^{\text {th }}$ DAS were reduced significantly at a higher dose of gamma rays.
While under in vivo condition, the response of gamma irradiation for shoot length at 250Gy \& 300Gy in Bahadurbhog and 200Gy \& 250Gy and 300Gy \& 350Gy in Blackjoha were exhibited statistically non-significant between each other (Figure 1). No significant differences could be found among 200Gy, 250Gy\& 300Gy in Badshabhog as well as in Blackjoha and also $350 \mathrm{~Gy} \& 400 \mathrm{~Gy}$ in all three germplasm for root length (Figure 1). 


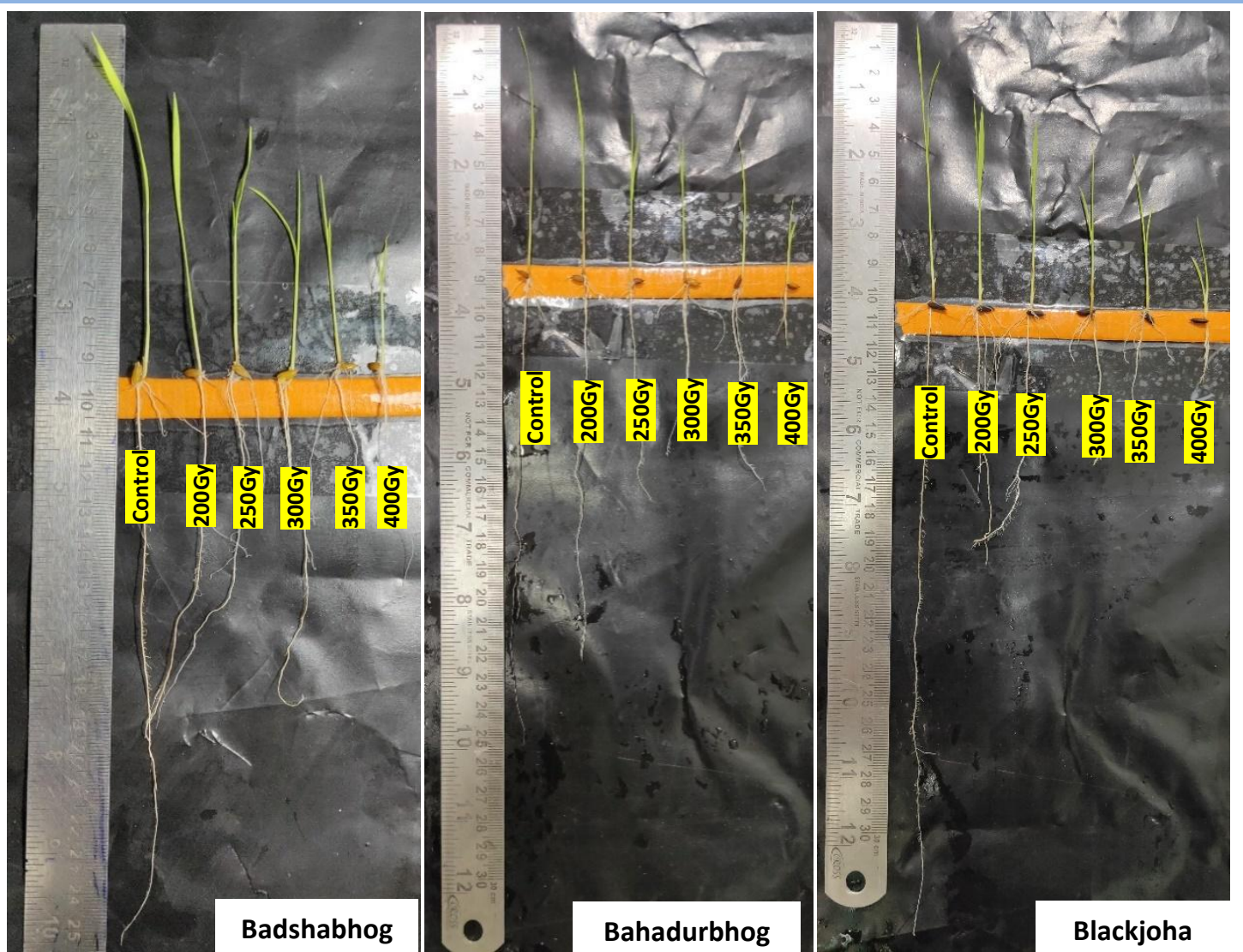

Figure 1 Gamma rays sensitivity on shoot and root length $(\mathrm{cm}$.$) at 14^{\text {th }}$ DAS under in vitro condition of all three non-basmati aromatic cultivars

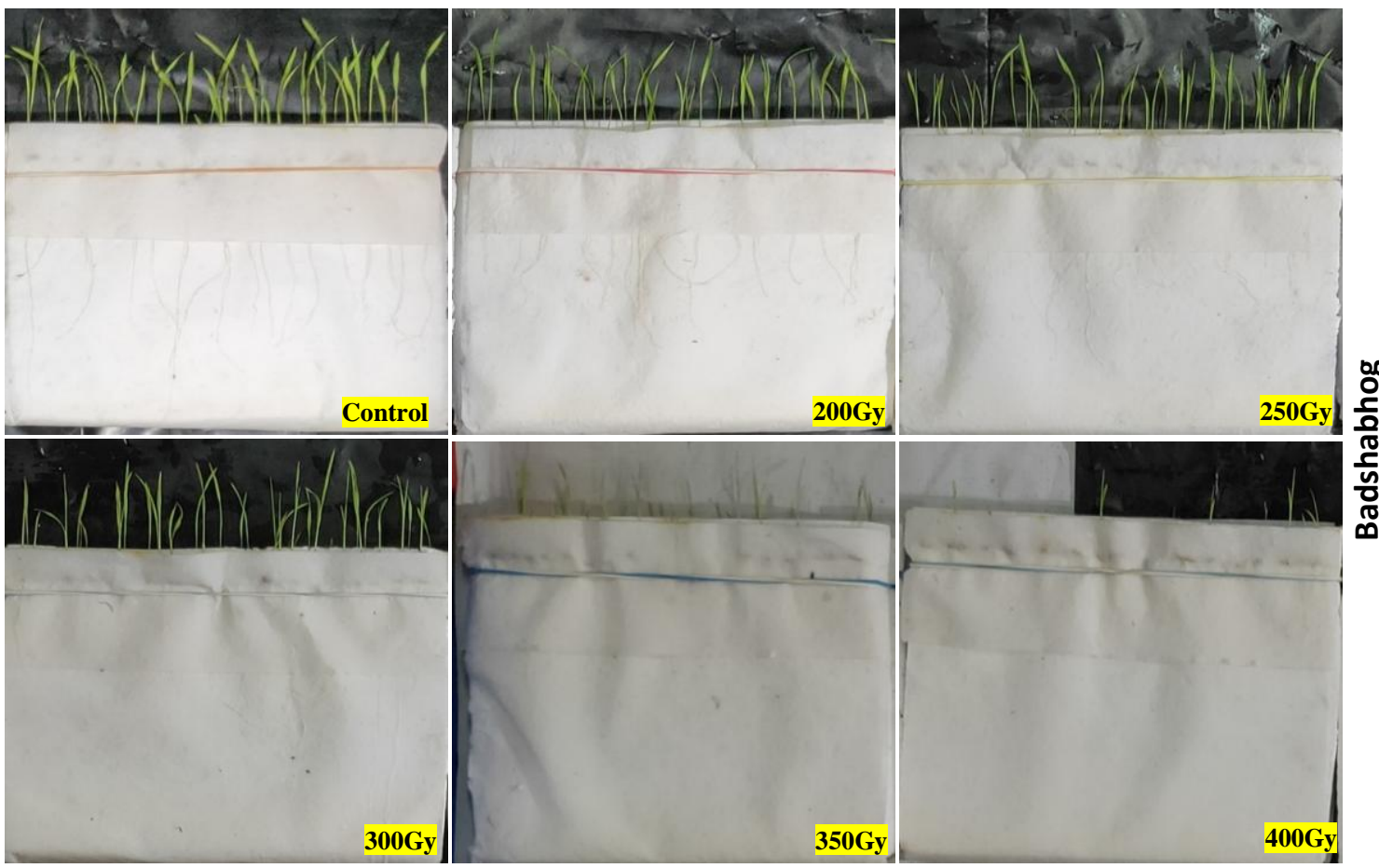

Figure 2a Gamma rays sensitivity on seedling survival at $14^{\text {th }}$ DAS under in vitro condition of Badshabhog

Journal of Experimental Biology and Agricultural Sciences http://www.jebas.org 


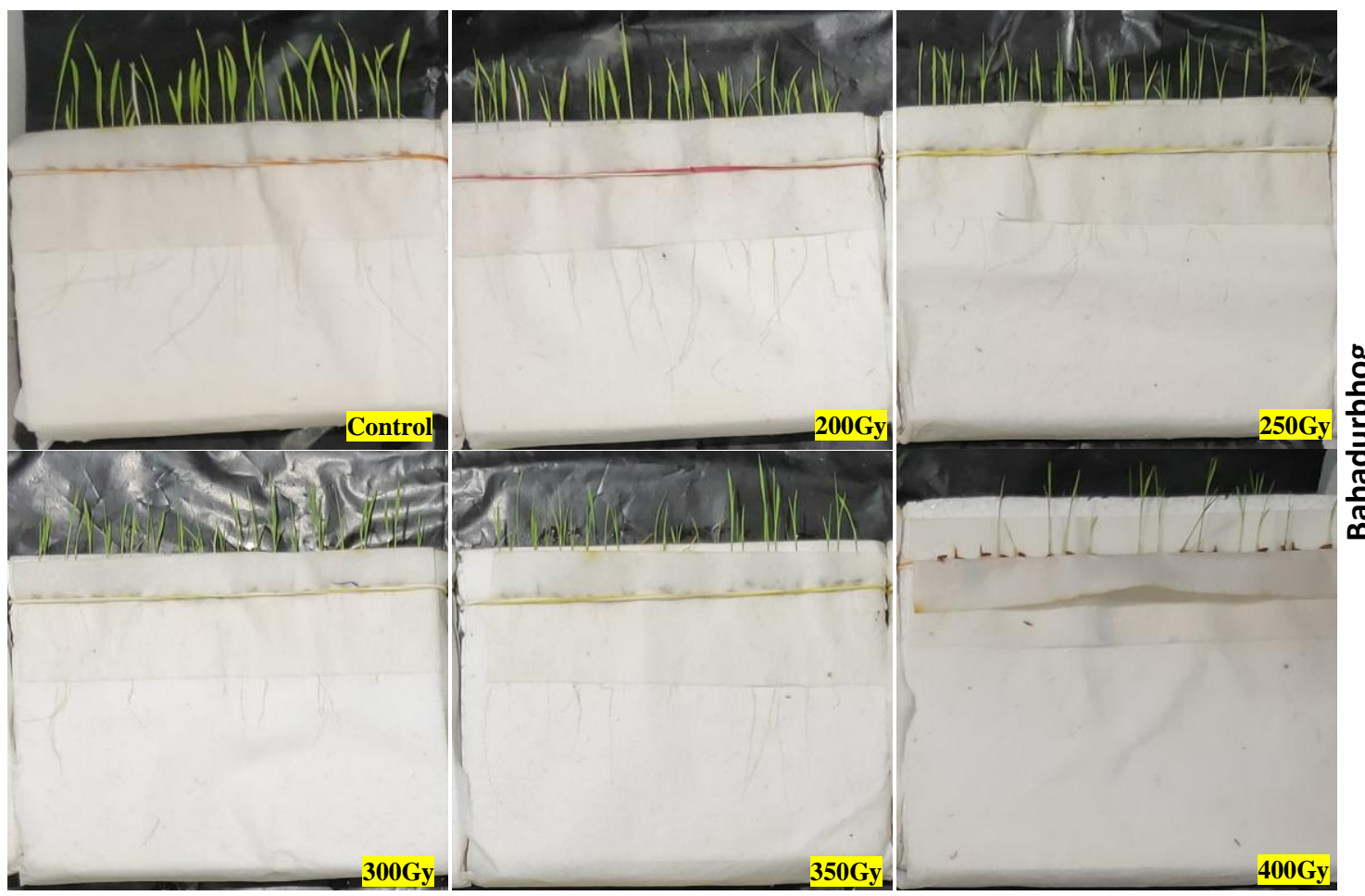

0
$\frac{0}{0}$
$\frac{0}{3}$
$\frac{2}{3}$
$\frac{0}{0}$
$\frac{1}{\pi}$
0

Figure $2 \mathrm{~b}$ Gamma rays sensitivity on seedling survival at $14^{\text {th }}$ DAS under in vitro condition of Bahadurbhog

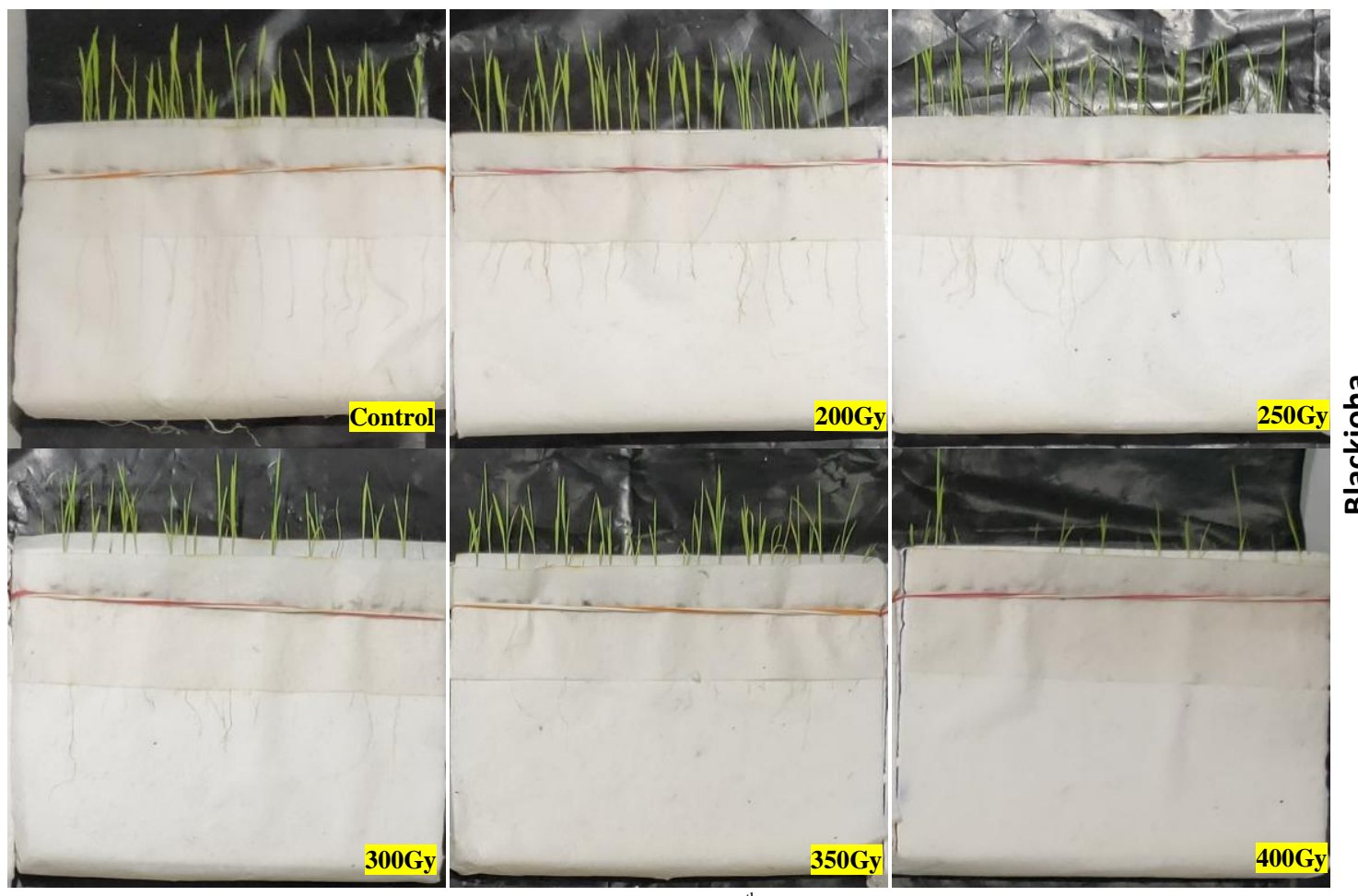

Figure 2c Gamma rays sensitivity on seedling survival at $14^{\text {th }}$ DAS under in vitro condition of Blackjoha 

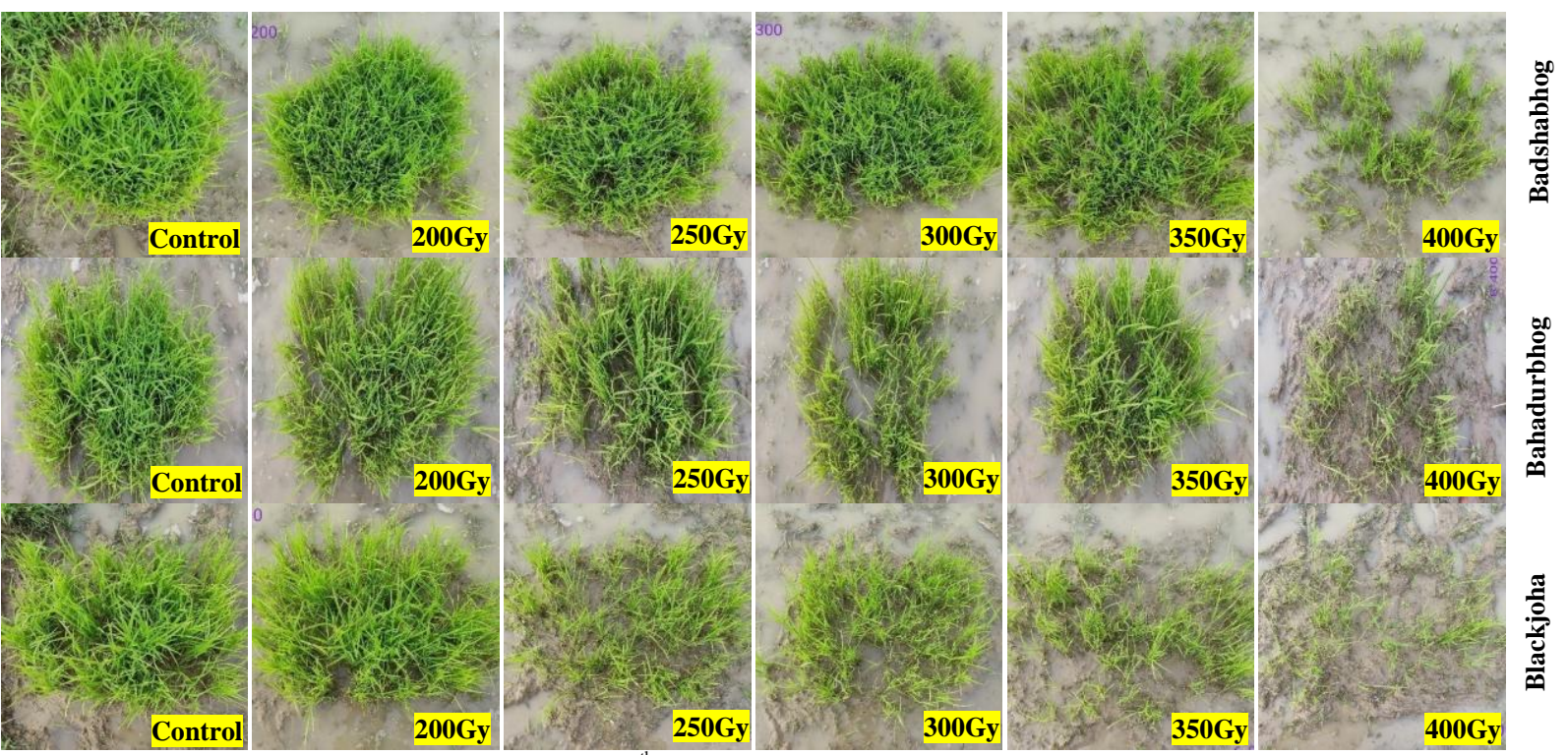

Figure 3 Gamma rays sensitivity on seedling survival at $25^{\text {th }}$ DAS under in vivo condition of all three non-basmati aromatic cultivars

Drastically reduction in seedling survival (\%) at $14^{\text {th }}$ DAS under in vitro(Fig. $2 \mathrm{a}, \mathrm{b}, \mathrm{c}$ ) and $25^{\text {th }}$ DAS under in vivo condition (Figure 3 ) was observed in each germplasm at 400Gy, which was significantly differed from control, 200Gy, 250Gy, 300Gy\& 350Gy except in Blackjoha where response at 350Gy \& 400Gy was noticed statistically nonsignificance under both in vitro as well as in vivo condition.

Experimental results on the seedling height in all three cultivars at $25^{\text {th }}$ DAS were significantly reduced under in vivo condition at 400Gy which was significantly differed from control and other doses. Non significant effect of irradiated treatments could be observed in Badshabhog at 0Gy (control) \& 200Gy while in the case of Bahadurbhog and Blackjoha this was reported at 300Gy\& 350Gy and 200Gy, 250Gy\& 300Gy respectively (Figure 4a, b, c).

\subsection{Determination of doses}

Effective doses were determined by using percent germination, percent seedling survival, and seedling growth parameters which were considered as an indication for immediate mutagenic effects. Estimation of the optimum dose was done by determining weight mean based on $\mathrm{LD}_{50}$ and $\mathrm{GR}_{30} / \mathrm{GR}_{50}$ doses of gamma rays (Table 2). The $\mathrm{LD}_{50}$ values were estimated from germination percentage and seedling survival percentage both under in vitro and in vivo conditions. The $\mathrm{GR}_{30} / \mathrm{GR}_{50}$ values were determined from the seedling growth characters.

Probit analysis was done to determine the $\mathrm{LD}_{50}$ value for gamma irradiation. Figure 5 showed that germination percentage under in vitro condition $\mathrm{LD}_{50}$ has arrived at $389.60 \mathrm{~Gy}$, 346.78Gy\& 332.02Gy for Badshabhog, Bahadurbhog, and Blackjoha, respectively. Under in vivo condition, $\mathrm{LD}_{50}$ was determined 363.95Gy, 327.04Gy \& 319.35Gy in Badshabhog, Bahadurbhog and Blackjoha respectively (Figure 6). In case of seedling survival (\%) under in vitro condition, $\mathrm{LD}_{50}$ was estimated at $364.82 \mathrm{~Gy}$, 333.99Gy \& 323.35Gy in Badshabhog, Bahadurbhog, and Blackjoha, respectively (Figure 7). Under in vivo condition maximum $\mathrm{LD}_{50}$ dose of gamma rays has arrived at 350.36Gy in Badshabhog followed by 312.13Gy in Bahadurbhog and 307.18Gy in Blackjoha (Figure 8).

By using linear regression equation, $\mathrm{GR}_{30}$ dose of gamma rays was determined and this was reported 292.76Gy\& 271.11Gy for shoot length in Badshabhog; 283.09Gy \& 312.90Gy in Bahadurbhog and $304.73 \mathrm{~Gy} \& 265.87 \mathrm{~Gy}$ in Blackjoha under in vitro and in vivo conditions, respectively (Figure 9, 10). In the case of root length characteristics, a drastic reduction was reported among the various seedling parameters. $\mathrm{GR}_{50}$ dose of gamma rays for root length was determined 273.30Gy, 305.77Gy \& 219Gy in Badshabhog, Bahadurbhogand Blackjoha respectively (Figure 11). In the case of seedling height under in vivo condition at $25^{\text {th }} \mathrm{DAS}, \mathrm{GR}_{30}$ dose of gamma rays arrived at $332.64 \mathrm{~Gy}, 322.16 \mathrm{~Gy} \& 368.24 \mathrm{~Gy}$ in the case of Badshabhog, Bahadurbhog, and Blackjoha, respectively (Figure 12).

Table 2 represented the in vitro and in vivo optimal radiation dose for selected rice cultivars; this was based on the weighted mean of $\mathrm{LD}_{50}$ and $\mathrm{GR}_{30} / \mathrm{GR}_{50}$ resulting from percent germination, percent seedling survival, and seedling growth parameters. The results on the optimal dose of gamma irradiation under in vitro and in vivo conditions were determined at 358.37 Gy \& 346.10Gy for Badshabhog; 331.19Gy \& 319.17Gy for Bahadurbhog and 314.55Gy \& 314.05Gy for Blackjoha, respectively. 

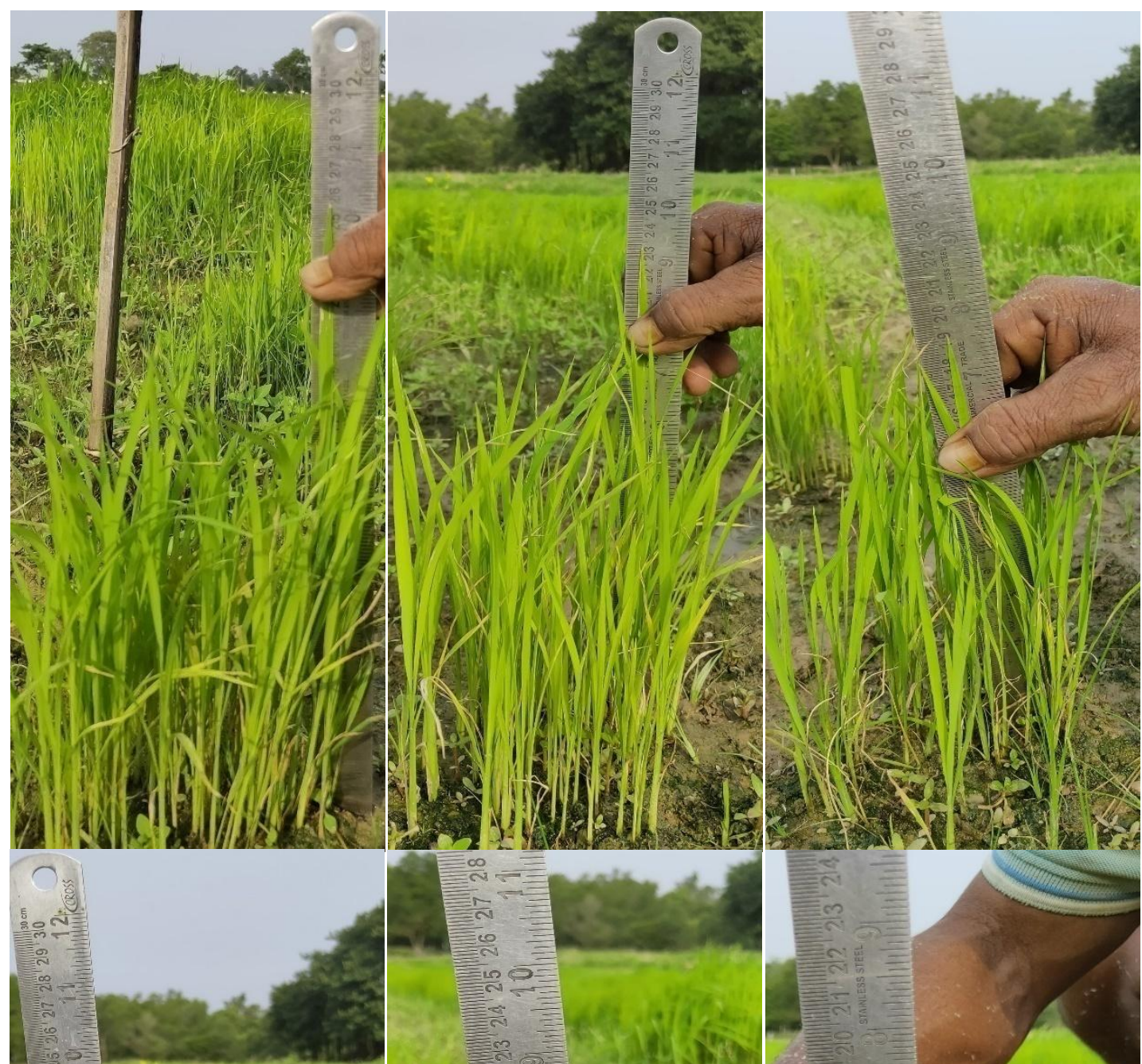

\section{0
$\frac{0}{0}$
$\frac{0}{0}$
$\frac{5}{5}$
$\frac{5}{8}$
$\frac{0}{0}$}

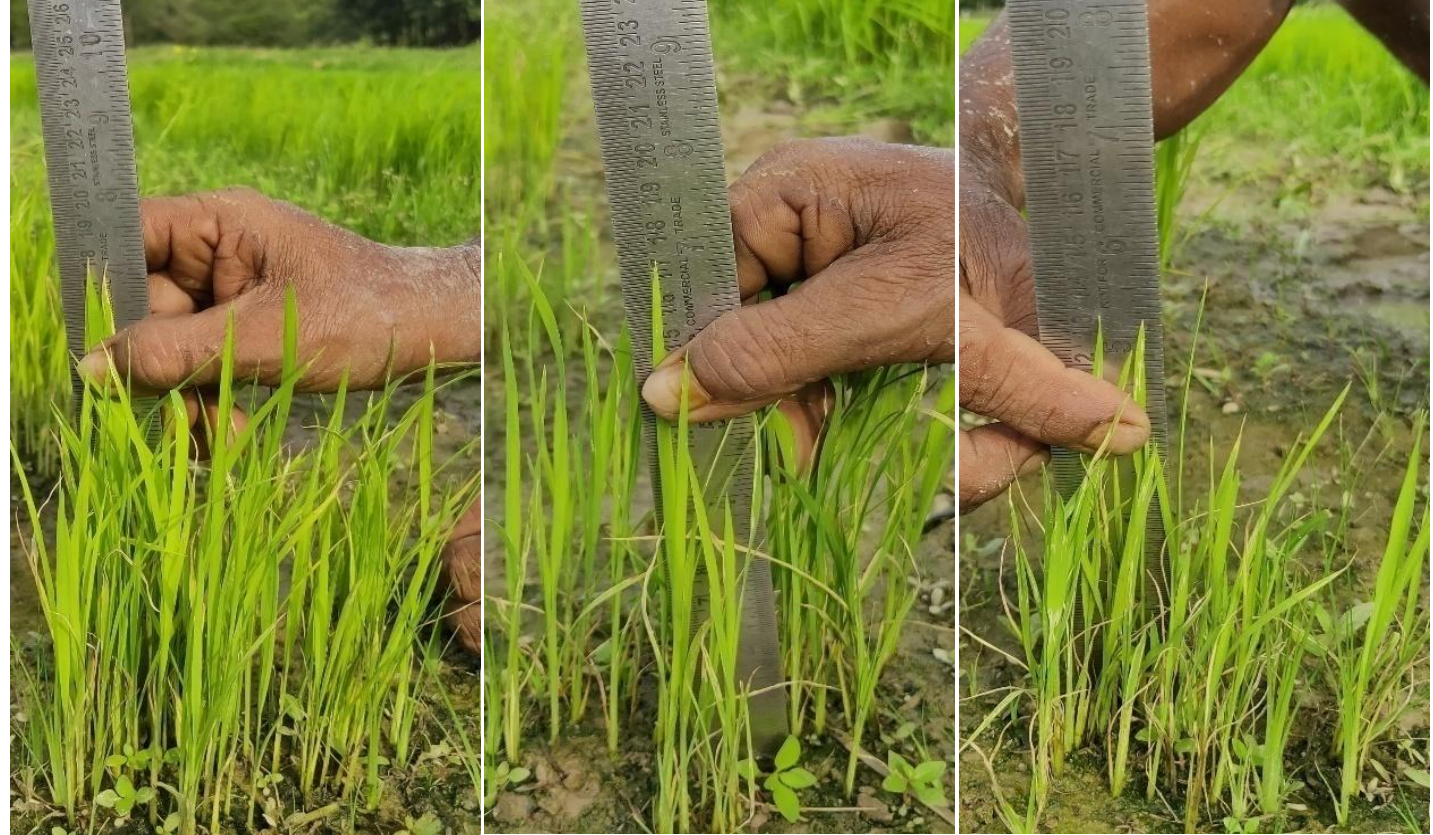

Figure $4 \mathrm{a}$ Gamma rays sensitivity on seedling height $\left(\mathrm{cm}\right.$.) at $25^{\text {th }}$ DAS under in vivo condition of Badshabhog

Journal of Experimental Biology and Agricultural Sciences http://www.jebas.org 


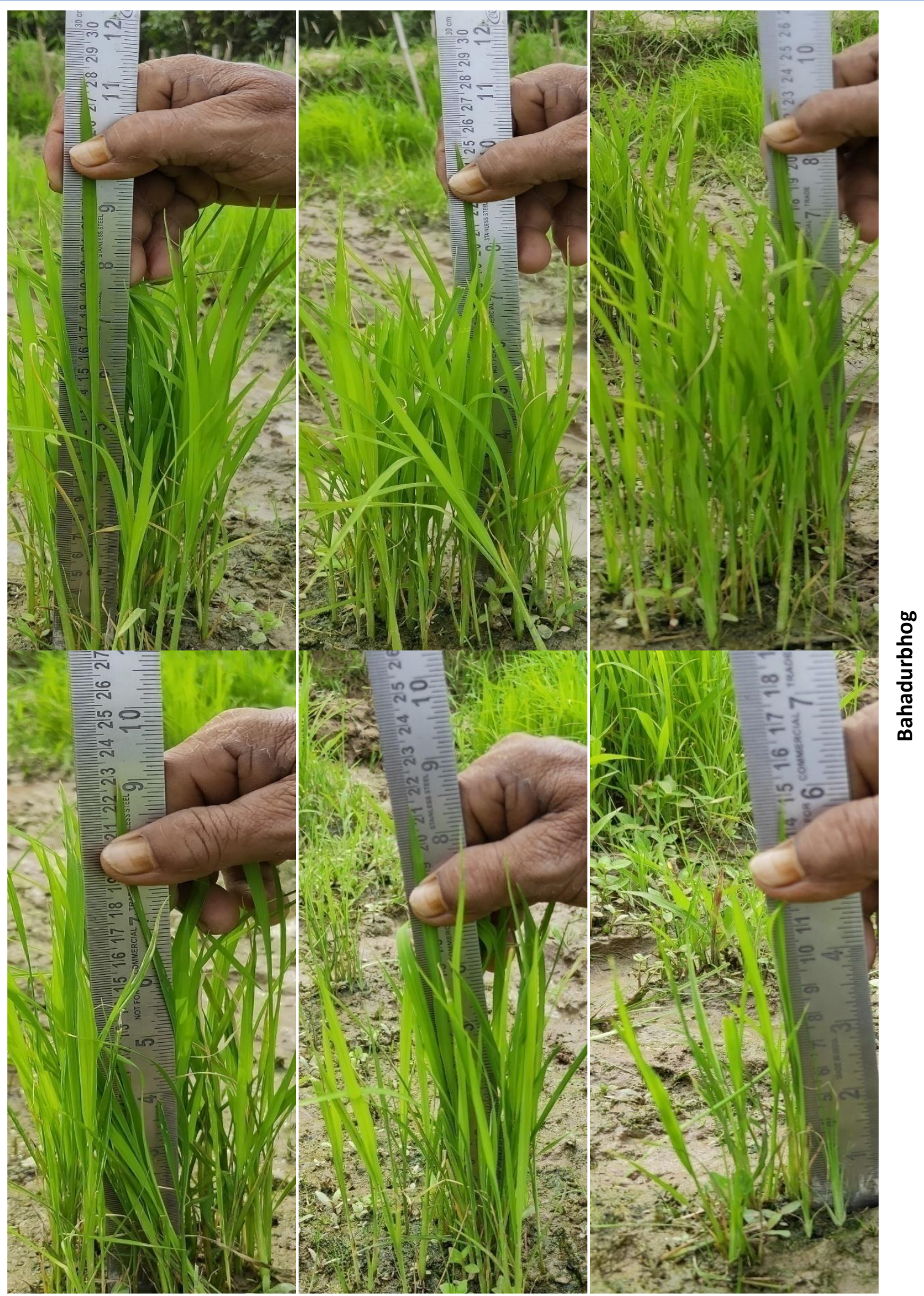

Figure $4 \mathrm{~b}$ Gamma rays sensitivity on seedling height $\left(\mathrm{cm}\right.$.) at $25^{\text {th }}$ DAS under in vivo condition of Bahadurbhog

Journal of Experimental Biology and Agricultural Sciences http://www.jebas.org 


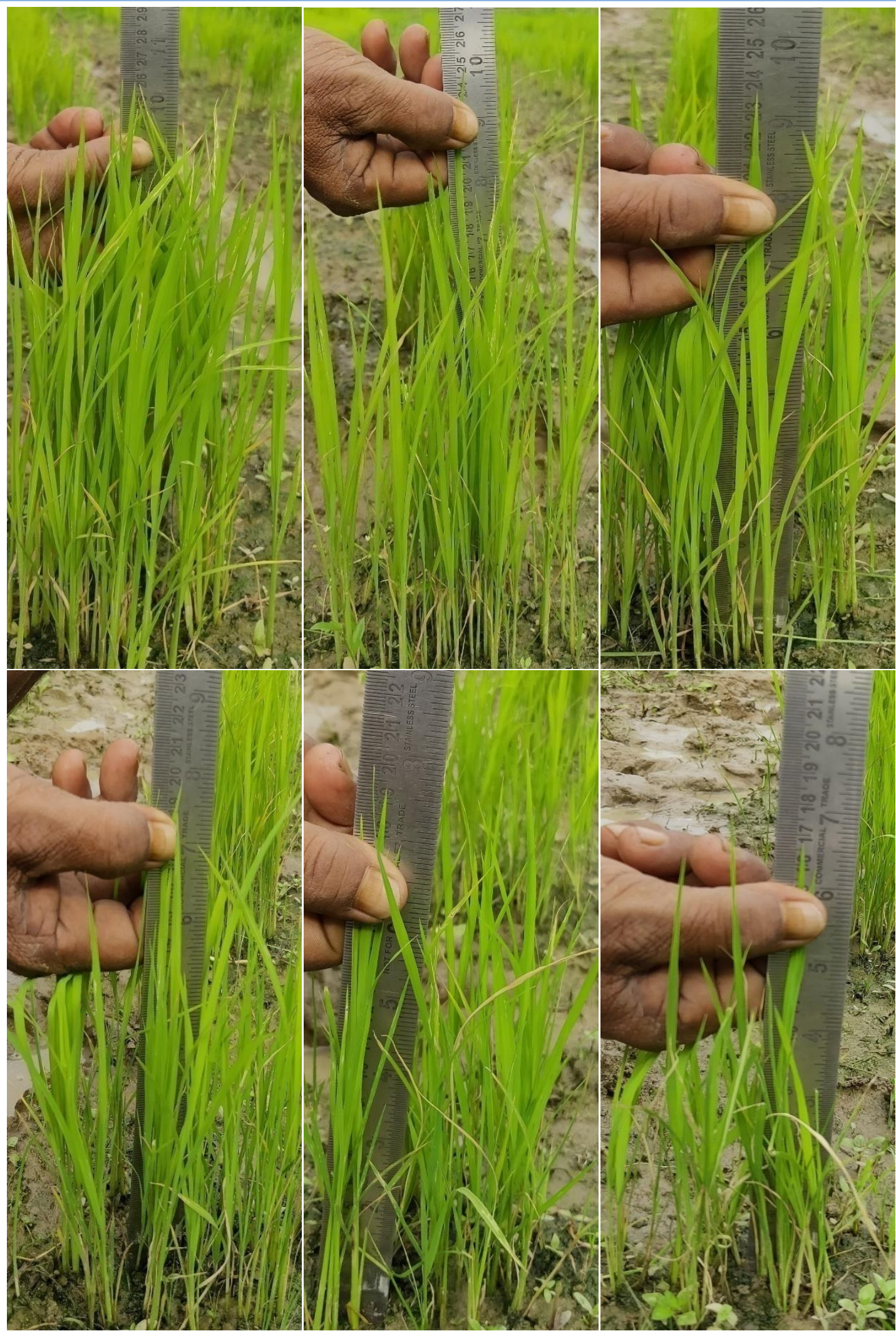

Figure $4 \mathrm{c}$ Gamma rays sensitivity on seedling height $\left(\mathrm{cm}\right.$.) at $25^{\text {th }}$ DAS under in vivo condition of Blackjoha

Journal of Experimental Biology and Agricultural Sciences http://www.jebas.org 


\begin{tabular}{|c|c|c|c|c|c|c|c|c|c|}
\hline \multirow{2}{*}{ Experiments } & \multirow{2}{*}{ Doses (Gy) } & \multirow{2}{*}{ Parameters } & \multirow{2}{*}{$\begin{array}{l}\text { Weighting } \\
\text { factors }(w)\end{array}$} & \multicolumn{2}{|c|}{ Badshabhog } & \multicolumn{2}{|c|}{ Bahadurbhog } & \multicolumn{2}{|c|}{ Blackjoha } \\
\hline & & & & $x$ & $w x$ & $x$ & $w x$ & $x$ & $w x$ \\
\hline \multirow{6}{*}{ In vitro } & \multirow{2}{*}{$\mathrm{LD}_{50}$} & Germination \% & 40 & 389.6 & 15584 & 346.78 & 13871.2 & 332.02 & 13280.8 \\
\hline & & Seedling survival $\%$ & 40 & 364.82 & 14592.8 & 333.99 & 13359.6 & 323.35 & 12934 \\
\hline & $\mathrm{GR}_{30}$ & Shoot length & 10 & 292.76 & 2927.6 & 283.09 & 2830.9 & 304.73 & 3047.3 \\
\hline & \multirow[t]{2}{*}{$\mathrm{GR}_{50}$} & Root length & 10 & 273.3 & 2733 & 305.77 & 3057.7 & 219.24 & 2192.4 \\
\hline & & $\operatorname{SUM}(\Sigma)$ & 100 & & 35837.4 & & 33119.4 & & 31454.5 \\
\hline & Optimal radiation & Weighed mean $(\Sigma w x / \Sigma w)$ & & & 358.374 & & 331.194 & & 314.545 \\
\hline \multirow{6}{*}{ In vivo } & \multirow{2}{*}{$\mathrm{LD}_{50}$} & Germination \% & 40 & 363.95 & 14558 & 327.04 & 13081.6 & 319.42 & 12776.8 \\
\hline & & Seedling survival $\%$ & 40 & 350.36 & 14014.4 & 312.13 & 12485.2 & 307.18 & 12287.2 \\
\hline & \multirow{2}{*}{$\mathrm{GR}_{30}$} & Shoot length & 10 & 271.11 & 2711.1 & 312.9 & 3129 & 265.87 & 2658.7 \\
\hline & & Seedling height & 10 & 332.64 & 3326.4 & 322.16 & 3221.6 & 368.24 & 3682.4 \\
\hline & & $\operatorname{SUM}(\Sigma)$ & 100 & & 34609.9 & & 31917.4 & & 31405.1 \\
\hline & Optimal radiation & Weighed mean $(\Sigma w x / \Sigma w)$ & & & 346.099 & & 319.174 & & 314.051 \\
\hline
\end{tabular}

Where, $w x$ is the corresponding weighting factor; $x$ is the $\mathrm{LD}_{50}$ and $\mathrm{GR}_{30} / \mathrm{GR}_{50}$ values of respective parameters; $w x$ is the multiplication of $w$ and $x$.
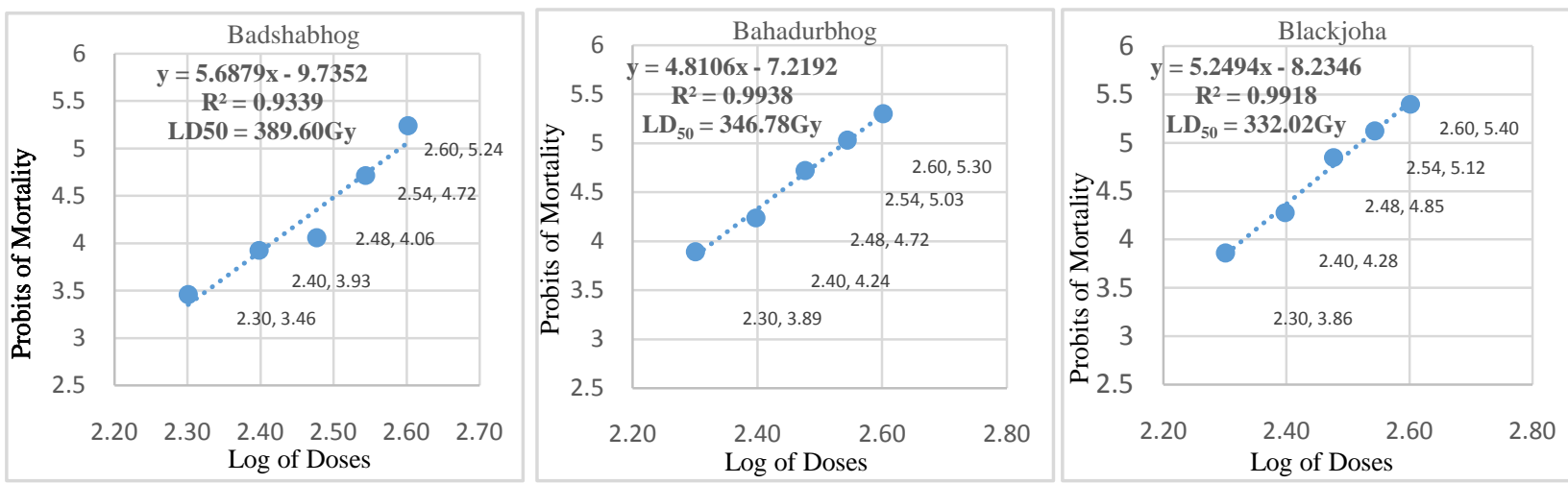

Figure 5 Determination of $\mathrm{LD}_{50}$ dose of gamma rays for seeds germination at $7^{\text {th }}$ DAS under in vitro condition in all three non-basmati aromatic cultivars
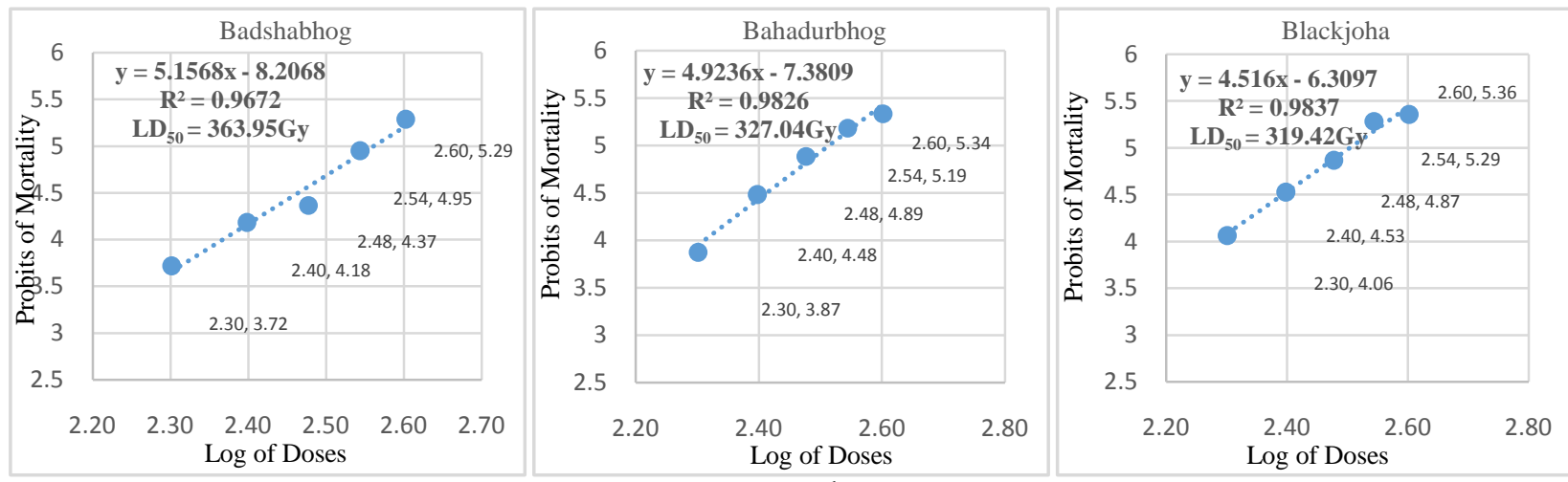

Figure 6 Determination of $\mathrm{LD}_{50}$ dose of gamma rays for seeds germination at $7^{\text {th }}$ DAS under in vivo condition in all three non-basmati aromatic cultivars

Journal of Experimental Biology and Agricultural Sciences http://www.jebas.org 

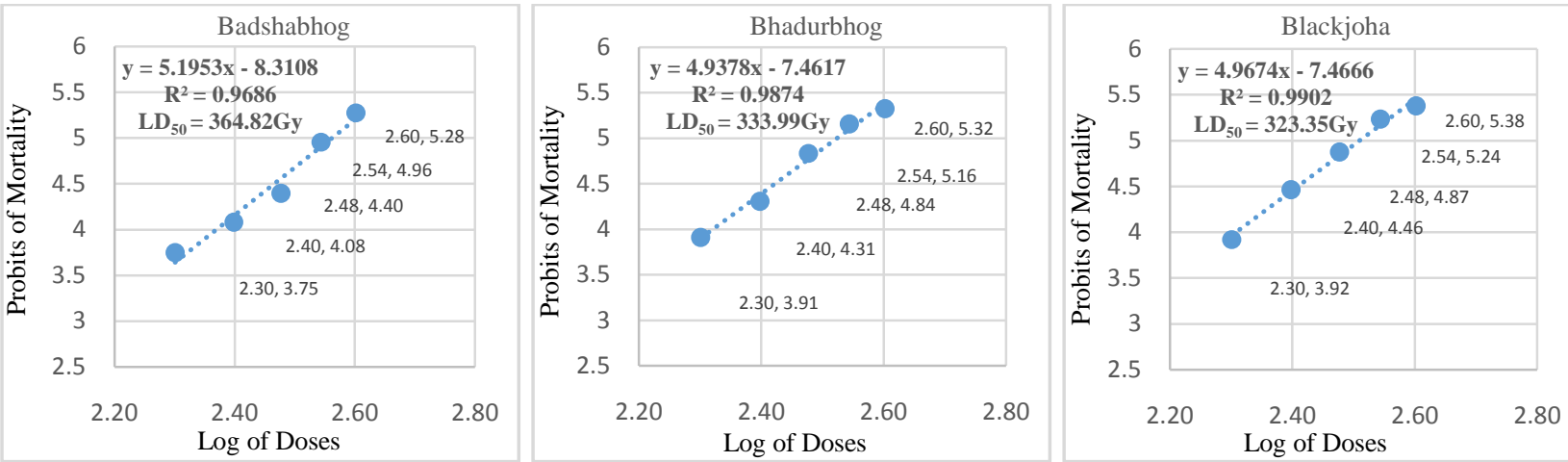

Figure 7 Determination of $\mathrm{LD}_{50}$ dose of gamma rays for seedlings survival at $14^{\text {th }} \mathrm{DAS}$ under in vitro condition in all three non-basmati aromatic cultivars
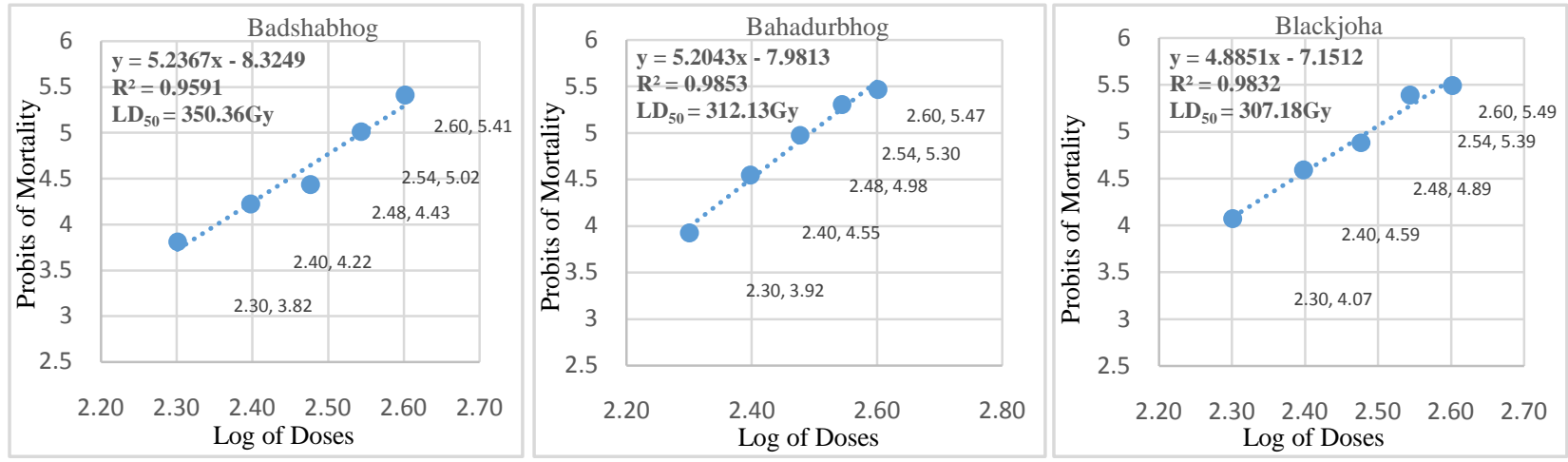

Figure 8 Determination of $\mathrm{LD}_{50}$ dose of gamma rays for seedlings survival at $25^{\text {th }} \mathrm{DAS}$ under in vivo condition in all three non-basmati aromatic cultivars
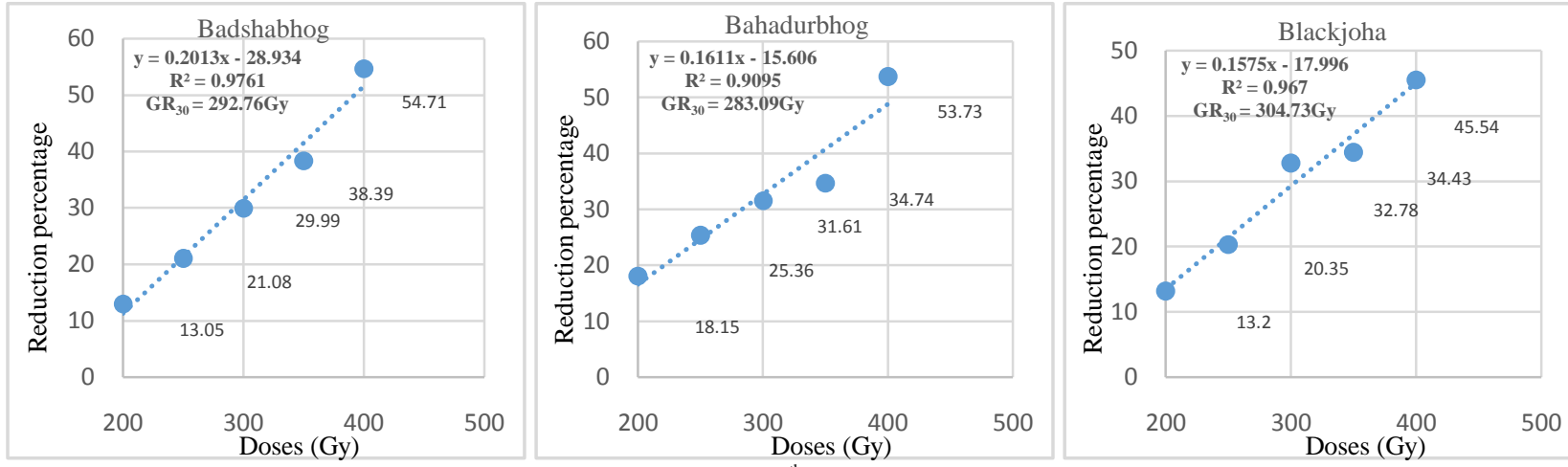

Figure 9 Determination of $\mathrm{GR}_{30}$ dose of gamma rays for shoot length at $14^{\text {th }}$ DAS under in vitro condition in all three non-basmati aromatic cultivars
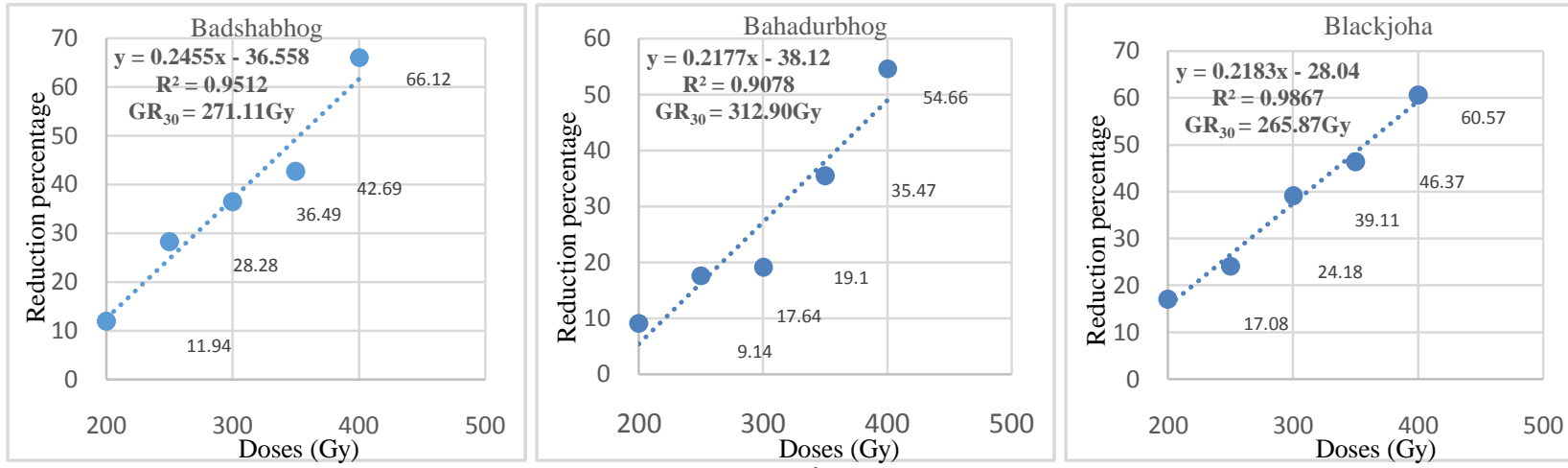

Figure 10 Determination of $\mathrm{GR}_{30}$ dose of gamma rays for shoot length at $14^{\text {th }}$ DAS under in vivo condition in all three non-basmati aromatic cultivars

Journal of Experimental Biology and Agricultural Sciences http://www.jebas.org 

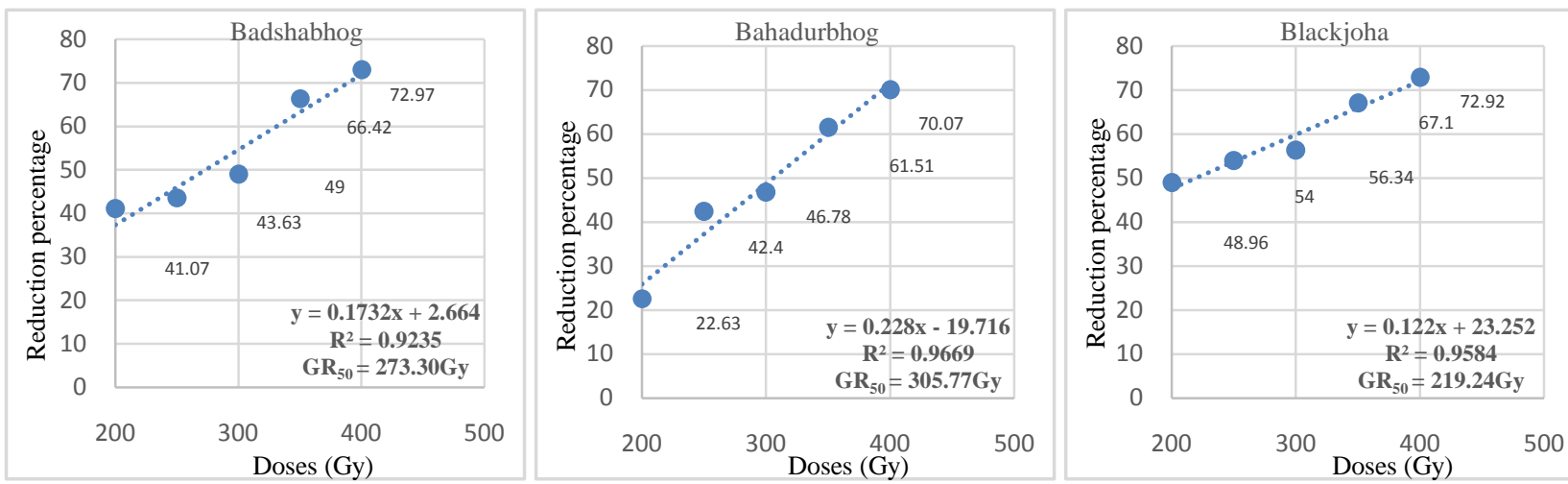

Figure 11 Determination of $\mathrm{GR}_{50}$ dose of gamma rays for root length at $14^{\text {th }} \mathrm{DAS}$ under in vitro condition in all three non-basmati aromatic cultivars
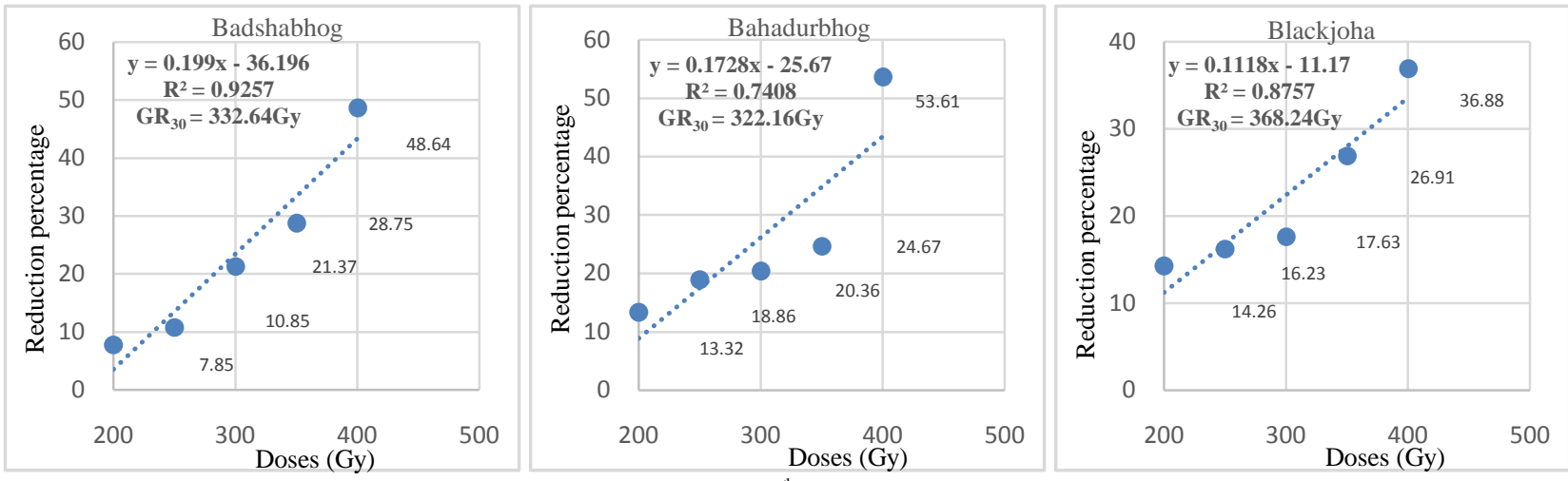

Figure 12 Determination of $\mathrm{GR}_{30}$ dose of gamma rays for seedling height at $25^{\text {th }} \mathrm{DAS}$ under in vivo condition in all three non-basmati aromatic cultivars

\subsection{Effects of gamma rays on quantitative traits}

The effects of gamma rays on plant height, number of effective tillers, panicle length, panicle exertion, number of filled grains, percent spikelet fertility, and grain yield were represented in Table 3.

\subsubsection{Plant height}

Short height plant was obtained at a higher dose in all three genotypes. Decreasing of plant height was not significant with increasing dose but a sharp reduction was observed in higher doses in all three genotypes. However, the plant height was not significantly reduced in all doses of gamma-ray received. Plant height of gamma-irradiated plants and control plants (unirradiated) differed significantly in all three genotypes except between 250Gy \& 350Gy in Badshabhog as well as Bahadurbhog; and 350Gy\& 400Gy in Blackjoha.

\subsubsection{Number of effective tillers}

Effective tiller or the production of lateral branches is an important agronomic trait that regulates shoot framing and grain production in rice. Based on the findings, the number of effective tillers produced per plant was significantly influenced by the dose applied. A significant increase in the number of effective tillers/hill was recorded at 250Gy \& 350Gy dose in Bahadurbhog, while in the case of Badshabhoga significant reduction was observed at 300Gy, 350Gy \&400Gy doses. No significant effect of radiation treatment could be found in Blackjoha.

\subsubsection{Panicle length}

Panicle length is one aspect of panicle architecture and is usually measured as an important yield-related trait that strongly affects yield components such as grain number, grain density, etc. In Badshabhog, significant short panicle length was observed at a higher dose. No significant effect of radiation treatment could be observed in the rest two genotypes.

\subsubsection{Panicle exertion}

Panicle exertion seems to be related to many other traits in rice such as plant height, panicle length, and biomass production. Plant stature and panicle exertion are associated with each other. A significant reduction in panicle exertion was recorded at 200Gy dose onwards in Bahadurbhog and Blackjoha while in Badshabhog effects of all five doses were statistically at par with each other. 
Table 3 Gamma rays sensitivity for various quantitative traits

\begin{tabular}{|c|c|c|c|c|c|c|c|}
\hline Treatments & $\begin{array}{l}\text { Plant height } \\
(\mathrm{cm})\end{array}$ & $\begin{array}{c}\text { Panicle } \\
\text { length }(\mathrm{cm})\end{array}$ & $\begin{array}{l}\text { Panicle } \\
\text { exertion } \\
(\mathrm{cm})\end{array}$ & $\begin{array}{l}\text { Number of } \\
\text { effective } \\
\text { tillers/hill }\end{array}$ & $\begin{array}{c}\text { Number of } \\
\text { filled grains/panicle }\end{array}$ & $\begin{array}{c}\text { Spikelet } \\
\text { fertility \% }\end{array}$ & $\begin{array}{l}\text { Grain yield } \\
\text { (g/plant) }\end{array}$ \\
\hline \multicolumn{8}{|c|}{ Badshabhog } \\
\hline Control & $156.15 \mathrm{a}$ & $27.56 \mathrm{a}$ & $16.88 \mathrm{a}$ & $11.24 \mathrm{a}$ & $194.20 \mathrm{a}$ & $74.16 \mathrm{a}$ & $22.43 \mathrm{a}$ \\
\hline 200Gy & $153.53 \mathrm{ab}$ & $27.16 \mathrm{a}$ & $15.36 \mathrm{ab}$ & $11.22 \mathrm{a}$ & $146.78 b$ & $61.53 b$ & $16.73 b$ \\
\hline 250Gy & $151.49 b$ & $26.51 \mathrm{ab}$ & $13.27 b$ & $11.13 \mathrm{a}$ & $127.36 b c$ & $49.69 b c$ & $14.99 \mathrm{~b}$ \\
\hline 300Gy & $150.17 \mathrm{~b}$ & $25.31 b c$ & $13.68 b$ & $9.73 b$ & $103.00 \mathrm{c}$ & $41.44 c$ & $11.90 \mathrm{c}$ \\
\hline 350Gy & $145.98 \mathrm{c}$ & $25.78 b c$ & $13.95 b$ & $8.42 \mathrm{c}$ & $100.73 c$ & $41.03 c$ & $9.14 \mathrm{c}$ \\
\hline 400Gy & $141.61 d$ & $25.08 \mathrm{c}$ & $13.95 b$ & $8.76 b c$ & $94.73 c$ & $37.33 \mathrm{c}$ & $9.16 \mathrm{c}$ \\
\hline Mean & 149.82 & 26.23 & 14.52 & 10.09 & 127.80 & 50.86 & 14.06 \\
\hline S.Em & 1.04 & 0.40 & 0.65 & 0.34 & 10.89 & 4.03 & 0.97 \\
\hline $\mathrm{CV}$ & 1.20 & 2.62 & 7.77 & 5.82 & 14.75 & 13.71 & 11.95 \\
\hline F-Test & $* *$ & $* *$ & $*$ & $* *$ & $* *$ & $* *$ & $* *$ \\
\hline \multicolumn{8}{|c|}{ Bahadurbhog } \\
\hline Control & $162.70 \mathrm{a}$ & 24.45 & $18.10 \mathrm{a}$ & $10.67 b c$ & $137.58 \mathrm{a}$ & $81.50 \mathrm{a}$ & $14.22 \mathrm{a}$ \\
\hline 200Gy & $158.33 \mathrm{ab}$ & 23.91 & $15.64 b$ & $10.20 \mathrm{c}$ & $124.33 b$ & $72.94 b$ & $9.78 b$ \\
\hline 250Gy & $153.70 \mathrm{bc}$ & 24.58 & $15.25 b c$ & $11.13 \mathrm{ab}$ & $109.71 \mathrm{c}$ & $65.16 \mathrm{c}$ & $8.81 \mathrm{~b}$ \\
\hline 300Gy & $153.93 \mathrm{bc}$ & 25.54 & $14.93 b c$ & $10.80 b c$ & $97.42 \mathrm{~d}$ & $51.12 d$ & $7.41 \mathrm{c}$ \\
\hline 350Gy & $149.19 \mathrm{~cd}$ & 24.82 & $14.39 \mathrm{~cd}$ & $11.53 \mathrm{a}$ & $71.78 \mathrm{e}$ & $41.11 \mathrm{e}$ & $6.36 \mathrm{~cd}$ \\
\hline 400Gy & $144.81 d$ & 25.84 & $13.52 \mathrm{~d}$ & $10.53 b c$ & $63.51 \mathrm{e}$ & $34.18 \mathrm{f}$ & $5.56 \mathrm{~d}$ \\
\hline Mean & 153.78 & 24.86 & 15.30 & 10.81 & 100.72 & 57.67 & 8.69 \\
\hline S.Em & 1.66 & 0.70 & 0.27 & 0.20 & 3.30 & 0.57 & 0.43 \\
\hline $\mathrm{CV}$ & 1.87 & 4.88 & 3.04 & 3.16 & 5.67 & 1.71 & 8.51 \\
\hline F-Test & $* *$ & NS & $* *$ & $*$ & $* *$ & $* *$ & $* *$ \\
\hline \multicolumn{8}{|c|}{ Blackjoha } \\
\hline Control & $162.14 \mathrm{a}$ & 22.31 & $16.39 \mathrm{a}$ & 11.13 & $90.02 \mathrm{a}$ & $75.09 \mathrm{a}$ & $12.43 \mathrm{a}$ \\
\hline 200Gy & $157.87 \mathrm{~b}$ & 22.42 & $15.28 b$ & 11.53 & $79.60 \mathrm{~b}$ & $63.84 b$ & $9.94 b$ \\
\hline 250Gy & $154.58 \mathrm{c}$ & 23.02 & $13.66 \mathrm{c}$ & 10.20 & $77.02 \mathrm{~b}$ & $55.90 \mathrm{c}$ & $8.40 \mathrm{c}$ \\
\hline 300Gy & $148.43 \mathrm{~d}$ & 22.93 & $12.13 \mathrm{~d}$ & 10.53 & $67.91 \mathrm{c}$ & $49.23 \mathrm{~d}$ & $6.09 \mathrm{~d}$ \\
\hline 350Gy & $144.73 \mathrm{e}$ & 22.05 & $11.35 \mathrm{e}$ & 10.33 & $46.96 \mathrm{~d}$ & $41.40 \mathrm{e}$ & $4.22 \mathrm{e}$ \\
\hline 400Gy & $142.77 \mathrm{e}$ & 22.44 & $9.75 f$ & 10.40 & $49.07 \mathrm{~d}$ & $38.37 f$ & $3.38 \mathrm{f}$ \\
\hline Mean & 151.75 & 22.53 & 13.09 & 10.69 & 68.43 & 53.97 & 7.41 \\
\hline S.Em & 0.95 & 0.40 & 0.23 & 0.43 & 2.76 & 0.84 & 0.26 \\
\hline $\mathrm{CV}$ & 1.08 & 3.07 & 3.08 & 6.95 & 6.97 & 2.69 & 6.10 \\
\hline F-Test & $* *$ & NS & $* *$ & NS & $* *$ & $* *$ & $* *$ \\
\hline
\end{tabular}

*, ** and NS: significant at the 0.05,0.01 level of probability and not significant, respectively; S.Em: standard error due to mean; CV: coefficient of variation; $\mathrm{F}$-Test: significance test. 
Table 4 Reduction percentage on various quantitative traits

\begin{tabular}{|c|c|c|c|c|c|c|c|c|c|c|c|c|c|c|}
\hline \multirow{2}{*}{ Treatments } & \multicolumn{2}{|c|}{ Plant height $(\mathrm{cm})$} & \multicolumn{2}{|c|}{$\begin{array}{l}\text { Panicle length } \\
(\mathrm{cm})\end{array}$} & \multicolumn{2}{|c|}{$\begin{array}{l}\text { Panicle exertion } \\
(\mathrm{cm})\end{array}$} & \multicolumn{2}{|c|}{$\begin{array}{c}\text { Number of } \\
\text { effective } \\
\text { tillers/hill }\end{array}$} & \multicolumn{2}{|c|}{$\begin{array}{l}\text { Number of } \\
\text { filled grains/ } \\
\text { panicle }\end{array}$} & \multicolumn{2}{|c|}{$\begin{array}{l}\text { Spikelet fertility } \\
\%\end{array}$} & \multicolumn{2}{|c|}{$\begin{array}{l}\text { Grain yield } \\
\text { (g/plant) }\end{array}$} \\
\hline & $\begin{array}{c}\% \\
\text { over } \\
\text { control }\end{array}$ & $\begin{array}{c}\% \\
\text { reduction }\end{array}$ & $\begin{array}{c}\% \\
\text { over } \\
\text { control }\end{array}$ & $\begin{array}{c}\% \\
\text { reduction }\end{array}$ & $\begin{array}{c}\% \\
\text { over } \\
\text { control }\end{array}$ & $\begin{array}{c}\% \\
\text { reduction }\end{array}$ & $\begin{array}{c}\% \\
\text { over } \\
\text { control }\end{array}$ & $\begin{array}{c}\% \\
\text { reduction }\end{array}$ & $\begin{array}{c}\% \\
\text { over } \\
\text { control }\end{array}$ & $\begin{array}{c}\% \\
\text { reduction }\end{array}$ & $\begin{array}{c}\% \\
\text { over } \\
\text { control }\end{array}$ & $\stackrel{\%}{\%}$ & $\begin{array}{c}\% \\
\text { over } \\
\text { control }\end{array}$ & $\begin{array}{c}\% \\
\text { reduction }\end{array}$ \\
\hline \multicolumn{15}{|c|}{ Badshabhog } \\
\hline Control & 100.00 & 0.00 & 100.00 & 0.00 & 100.00 & 0.00 & 100.00 & 0.00 & 100.00 & 0.00 & 100.00 & 0.00 & 100.00 & 0.00 \\
\hline 200Gy & 98.32 & 1.68 & 98.54 & 1.46 & 90.97 & 9.03 & 99.80 & 0.20 & 75.58 & 24.42 & 82.96 & 17.04 & 74.58 & 25.42 \\
\hline 250Gy & 97.02 & 2.98 & 96.17 & 3.83 & 78.60 & 21.40 & 99.01 & 0.99 & 65.58 & 34.42 & 67.00 & 33.00 & 66.81 & 33.19 \\
\hline 300Gy & 96.17 & 3.83 & 91.82 & 8.18 & 81.05 & 18.95 & 86.56 & 13.44 & 53.04 & 46.96 & 55.87 & 44.13 & 53.07 & 46.93 \\
\hline 350Gy & 93.49 & 6.51 & 93.53 & 6.47 & 82.61 & 17.39 & 74.90 & 25.10 & 51.87 & 48.13 & 55.32 & 44.68 & 40.74 & 59.26 \\
\hline 400Gy & 90.69 & 9.31 & 90.99 & 9.01 & 82.64 & 17.36 & 77.87 & 22.13 & 48.78 & 51.22 & 50.33 & 49.67 & 40.84 & 59.16 \\
\hline \multicolumn{15}{|c|}{ Bahadurbhog } \\
\hline Control & 100.00 & 0.00 & 100.00 & 0.00 & 100.00 & 0.00 & 100.00 & 0.00 & 100.00 & 0.00 & 100.00 & 0.00 & 100.00 & 0.00 \\
\hline 200Gy & 97.31 & 2.69 & 97.82 & 2.18 & 86.41 & 13.59 & 95.63 & 4.37 & 90.37 & 9.63 & 89.50 & 10.50 & 68.76 & 31.24 \\
\hline 250Gy & 94.47 & 5.53 & 100.55 & - & 84.24 & 15.76 & 104.38 & - & 79.74 & 20.26 & 79.96 & 20.04 & 61.93 & 38.07 \\
\hline 300Gy & 94.61 & 5.39 & 104.49 & - & 82.50 & 17.50 & 101.25 & - & 70.81 & 29.19 & 62.73 & 37.27 & 52.11 & 47.89 \\
\hline 350Gy & 91.69 & 8.31 & 101.53 & - & 79.48 & 20.52 & 108.13 & - & 52.17 & 47.83 & 50.45 & 49.55 & 44.75 & 55.25 \\
\hline 400Gy & 89.01 & 10.99 & 105.70 & - & 74.70 & 25.30 & 98.75 & 1.25 & 46.16 & 53.84 & 41.94 & 58.06 & 39.10 & 60.90 \\
\hline \multicolumn{15}{|c|}{ Blackjoha } \\
\hline Control & 100.00 & 0.00 & 100.00 & 0.00 & 100.00 & 0.00 & 100.00 & 0.00 & 100.00 & 0.00 & 100.00 & 0.00 & 100.00 & 0.00 \\
\hline 200Gy & 97.37 & 2.63 & 100.48 & - & 93.25 & 6.75 & 103.59 & - & 88.42 & 11.58 & 85.03 & 14.97 & 79.98 & 20.02 \\
\hline 250Gy & 95.34 & 4.66 & 103.19 & - & 83.36 & 16.64 & 91.62 & 8.38 & 85.56 & 14.44 & 74.44 & 25.56 & 67.63 & 32.37 \\
\hline 300Gy & 91.54 & 8.46 & 102.79 & - & 74.00 & 26.00 & 94.61 & 5.39 & 75.44 & 24.56 & 65.56 & 34.44 & 49.00 & 51.00 \\
\hline 350Gy & 89.26 & 10.74 & 98.81 & 1.19 & 69.28 & 30.72 & 92.81 & 7.19 & 52.16 & 47.84 & 55.14 & 44.86 & 33.93 & 66.07 \\
\hline 400Gy & 88.05 & 11.95 & 100.57 & - & 59.48 & 40.52 & 93.41 & 6.59 & 54.51 & 45.49 & 51.10 & 48.90 & 27.21 & 72.79 \\
\hline
\end{tabular}

\subsubsection{Number of filled grains}

Rice grain filling mainly depends upon standard agronomic practices. The tillering capacity is most important because late formed tillers fail to produce filled grains. From the study, the number of filled grain was reduced at increasing dose. In Badshabhog effect of 250Gy, 300Gy, 350Gy, and 400Gy; in Bahadurbhog 350Gy and 400Gy and Blackjoha effect of 200Gy \& 250Gy and 350Gy \& 400Gy were statistically not significant with each other.

\subsubsection{Percent Spikelet fertility}

Spikelet fertility (\%) in rice depends on important physiological processes e.g. anther dehiscence, pollen germination, pollination, and fertilization. Spikelet fertility percent was significantly reduced at a higher dose of gamma irradiation in linear trends except for 300Gy, 350Gy \& 400Gy in Badshabhog where the response was statistically at par.

\subsubsection{Grain yield}

Grain yield is one of the most important and complex traits in rice. Yield is determined by indirect traits like plant height, tillering ability, panicle length, grains/panicle, etc. A significant reduction in grain yield per plant from control was observed at all five doses in all three genotypes. The doses 200Gy \&250Gy and 300Gy, 350Gy \& 400Gy in Badshabhog; 200Gy \& 250Gy in Bahadurbhog were statistically no different.

\subsubsection{Percentage Reduction}

Table 4 displayed a reduction (\%) of quantitative traits. Drastic reduction $(\%)$ was observed in the number of filed grain, spikelet fertility (\%), and grain yield per plant. The highest reduction in the number of filled grains and spikelet fertility was observed at $53.84 \%$ and $58.06 \%$, respectively at higher irradiation (400Gy) of gamma rays in Bahadurbhog followed by Badshbhaog $(51.22 \%$ and $49.67 \%)$ and Blackjoha (45.49\% and $48.90 \%)$. Whereas

Journal of Experimental Biology and Agricultural Sciences http://www.jebas.org 
maximum reductions for grain yield $(72.79 \%)$ were noticed at higher irradiation (400Gy) in the case of Blackjoha followed by Bahadurbhog (60.90\%) and Badshabhog (59.16\%).

\section{Discussion}

\subsection{Effects of gamma rays on biological traits}

Knowledge of immediate effects on radiation and fixation of optimal radiation dose is very important to execute genetic improvement programme on these non-basmati aromatic cultivars namely Badshabhog, Bahadurbhog, and Blackjoha through gamma rays induced mutations.

The present investigation revealed that the gradual inhibition in germination (\%) was observed at a higher dose (400Gy) of gamma irradiation in Blackjoha followed by Bahadurbhog and Badshabhog. Such a dose-dependent decrease in germination percent was also reported by Vasline (2013) for gamma rays. Similar kinds of results are reports by Lalitha et al. (2019), Wijesena et al. (2019), and Yasmine et al. (2019). Reduced germination with high radiation might be due to higher physiological damage in seeds resulting from inhibition of auxin synthesis (Gordon, 1957), catalase, peroxidase, and cytochrome oxidase (Kleinhofs et al., 1974), cells death in the embryo part of seed (Olasupo et al., 2016).

The seedling survival percentage in all three cultivars was decreased progressively with the increasing dose of gamma irradiation due to inhibition of plant growth via alteration of physiological as well as morphological traits. The similar kind of findings was reported by Gowthami et al. (2017) and Lalitha et al. (2019).

Gaul (1977) reported that the damage to the biological material will be reflected in the germination and seedling survival. It may be considered as an indication for the mutagenic effects. The stimulating effect of radiation on germination may be inhibited to the activation of RNA or protein synthesis and it may be founded during the starting of germination (Chandrashekar, 2014).

Various seedlings parameters (shoot length, root length, and seedling height) through ionizing radiation offer a more valuable estimate for mutation breeding programme. Severe reduction in seedling parameters was caused by the highest dose (400Gy), while the highest expression for these characters was noticed through the lowest dose (200Gy). Similar results were reported by Gowthami et al. (2017). Different factors such as disturbances of balance between promoters, inhibitors of growth regulators, and changes in metabolic activity of cells have attributed to more sensitivity at higher doses of mutagens (Olasupo et al., 2016; Kumar \&Swati, 2017). The sensitivity of root growth to mutagens may be due to the simultaneous effect of mitotic arrest and the preponderance of cells in the $\mathrm{G}_{2}$ phase in the meristems because such phase of the cell cycle is more sensitive as compared to the $\mathrm{G}_{1}$ phase of the cell cycle to irradiation (Oney-Birol \& Balkan, 2019). Various explanations have been offered for the reduction in seedling growth due to higher activity of the antioxidants (Jan et al., 2012), alteration in ascorbic acid content and biochemical and physiological interference (Ussuf \& Nair, 1974), inhibit mitotic division in meristematic tissues (Khalil et al., 1986) and disturbs the hormone balance, synthesis of protein, water exchange, leaf gas-exchange and enzyme activity which may the possible causes of adverse effects of gamma rays on plant height (Khah \& Verma, 2015).

The optimal radiation dose is established through the lethal dose $\left(\mathrm{LD}_{50}\right)$ or growth reduction $\left(\mathrm{GR}_{30} / \mathrm{GR}_{50}\right)$ (Khalil et al., 2014). The $\mathrm{LD}_{50}$ was estimated from germination percent and seedling survival percent values. The growth reduction (GR) is one of the important factors to predict the radiosensitivity level in plants (Alvarez-Holguin et al., 2019; Kumar et al., 2018). It quantifies a dose where $50 \%$ of seeds can germinate, survive, and expose to their normal growth. In this study, in the case of shoot length (in vitro and in vivo condition) and seedling height (in vivo condition), the $\mathrm{GR}_{30}$ value was calculated instead of $\mathrm{GR}_{50}$. The reason behind that irradiation dose was more than 400Gy of gamma irradiation, were required to reduce $50 \%$ growth for all three cultivars, which crosses the limit of the irradiation dose. This indicates that irradiated doses in this study were safe for the parameters. However, the values of $\mathrm{LD}_{50}$ and $\mathrm{GR}_{30} / \mathrm{GR}_{50}$ in all variables under in vitro and in vivo conditions were ranged from 273.3 to $389.6 \mathrm{~Gy}$ and 271.11 to $363.95 \mathrm{~Gy}$ for Badshabhog; 283.09 to 346.78Gy and 312.13 to 327.04Gy for Bahadurbhog; 219.24 to 332.02Gy and 265.87 to $368.24 \mathrm{~Gy}$ for Blackjoha, respectively. Considering the wide range, a weighted mean was appraised to establish the optimal radiation dose of the gamma radiation in the seeds of these three cultivars. The optimal radiation dose for Badshabhog, Bahadurbhog, and Blackjoha are found to be 358.37Gy\& 346.09Gy, 331.19Gy\& 319.17Gy and 314.54Gy\& 314.05Gy under in vitro and in vivo conditions, respectively. Both values in each cultivar are very close to each other. This indicates gamma rays dose of 350-360Gy for Badshabhog, 320-330Gy for Bahadurbhog, and $315 \mathrm{~Gy}$ for Blackjoha may be an optimum dose for irradiation. Whereas, Blackjoha was more sensitive compare with the other two cultivars used in this experiment. According to Rutger (1992), the effective dosage of gamma rays generally varied from 150 to $300 \mathrm{~Gy}$ which permits 60 percent survival of seedling in rice. Many workers determined $\mathrm{LD}_{50}$ values from their experiments. The $\mathrm{LD}_{50}$ value of 238Gy, 232Gy \& 223Gy for Basmati 37, Basmati Pak and Super Basmati, respectively by Cheema \& Atta (2003); ranged between 345 to $423 \mathrm{~Gy}$ for 13 rice varieties by Harding et al. (2012); 230Gy for "Tarommahalli" landrace by Hallajian et al. ( 2014); 288 \& 354Gy for two rice cultivars by Ramchander et al. (2015); 353 Gy for Binadhan-14 and 241 Gy for Ashfal by Rani et 
al. (2016); 376.57Gy for Anna (R) 4 rice variety by Lalitha et al. (2019) were reported earlier. The $\mathrm{GR}_{50}$ value ranged between 350 to 500Gy for seedling height by Spencer-Lopes et al. (2018); 403.26Gy for shoot length and 246.31Gy for root length by Lalitha et al. (2019) were recorded previously.

\subsection{Effects on quantitative traits due to gamma rays}

Most of all quantitative traits under study were exhibited significant variation due to gamma irradiation in all three nonbasmati aromatic rice cultivars. A similar type of significant differences due to gamma irradiation for yield and yield associate traits was reported by Ramchander et al. (2015).

Chakraborty \& Kole (2008) reported that plant height decreased with an increase in the dose of gamma radiation. The results are in agreement with Sasikala \& Kalaiyarasi (2010). Various explanations have been offered for growth inhibition due to mutagenic treatments like auxin destruction (Joshi \& Gour, 1974) or inhibition of auxin synthesis, disbalance in the maintenance of nutritional level, failure of assimilatory mechanisms, inhibition of mitosis, interruption in DNA synthesis, and chromosomal damage with associated physiological changes (Riley, 1953).

The number of effective tillers plays a vital role in determining grain yield (Oladosu et al., 2014). The number of effective tillers is influenced by the cultivar and radiation doses. Badshabhog, Bahadurbhog, and Blackjoha variety possess 9 to 11 effective tillers per hill. However, a significant response in effective tillers/hill was recorded in Badshabhog and Bahadurbhog to radiation doses and Blackjoha where the response was statistically at par. Similar result was reported by Haris et al. (2013), in which gamma-ray radiation affects significantly the number of firstgeneration productive tillers $\left(\mathrm{M}_{1}\right)$. Purwanto et al. (2019) also reported that gamma irradiation produced an insignificant difference in the character of the tiller number in $\mathrm{M}_{1}$ generation. An increase in effective tillers/hill might have resulted from the stimulatory effect of mutagen.

Panicle length and panicle exertion were not affected much by radiation doses. Similarly, Sarawgi \& Soni (1993) reported that panicle length was not affected much by mutagenic treatment in the $\mathrm{M}_{1}$ generation. But the shift of mean value in some mutated progenies in the negative direction could be attributed to the deleterious effect of radiation.

Some stimulatory effects of gamma rays were observed on the number of filled grains/panicle. The higher reduction of spikelet fertility (\%) may be due to higher pollen sterility. Akilan et al. (2019) reported a higher percentage of spikelet sterility in gammaray induced rice mutants. The results revealed that the grain yield of the $\mathrm{M}_{1}$ plant was drastically decreased with an increasing dose of gamma rays in Blackjoha followed by Bahadurbhog and Badshabhog. These results are in agreement with the findings of Ramchander et al. (2015) and Lalitha et al., (2019). Reduction in grain yield per plant might be due to a large number of sterile spikelets and negative effects of other yield contributing traits.

\section{Conclusions}

The overall results indicated that, in general, all the biological traits and quantitative traits were decreased with an increase in the dose of gamma rays at a variable rate due to the negative effect of the mutation. However, Germination percent, Seedling survival, shoot length, root length, and seedling height parameters were affected by high doses of gamma radiations, which made it possible to determine the lethal dose $\left(\mathrm{LD}_{50}\right)$ and the growth reduction $\left(\mathrm{GR}_{30} / \mathrm{GR}_{50}\right)$. To attain the genetic improvement of specific traits for Badshabhog, Bahadurbhog, and Blackjoha rice cultivars, it recommends using the optimal radiation dose which causes a maximum of mutation with the minimum of damage to the plant, obtained through the weighting of both parameters (350360Gy for Badshabhog, 320-330Gy for Bahadurbhog and 315Gy for Blackjoha). According to the results, Blackjoha cultivar was highly sensitive to gamma rays followed by Bahadurbhog and Badshabhog. Moreover, the number of effective tillers/hill was increased in some of the irradiated population over control, which might be due to the stimulatory effect of mutagen while panicle length remained almost unaffected. Gamma rays also offered polygenic mutation which can help to improve important agronomic characters. Knowledge of this experiment will contribute to the development of new genetic material that can be utilized for the commercial cultivation of popular non-basmati aromatic rice in eastern India.

\section{Acknowledgments}

Authors are highly thankful to the Board of Research in Nuclear Science, Department of Atomic Energy, Government of India for providing financial support to conduct this study. The authors are grateful to Visva-Bharati University for providing necessary field and laboratory facilities.

\section{Conflicts of interest}

The authors declare that they have no conflicts of interest.

\section{References}

Abdelnour-Esquivel A, Perez J, Rojas M, Vargas W, Gatica-Arias A (2020) Use of gamma radiation to induce mutations in rice (Oryza sativa L.) and the selection of lines with tolerance to salinity and drought. In Vitro Cellular \& Developmental BiologyPlant 56: 88-97. 
Akilan M, Anand G, Vanniarajan C, Subramanian E, Anandhi K (2019) Study on the impact of mutagenic treatment on pollen and spikelet fertility and its relationship in rice (Oryza sativa L.). Electronic Journal of Plant Breeding 10: 525-534.

Alvarez-Holguin A, Raul Morales-Nieto C, Hugo AvendanoArrazate C, Corrales-Lerma R, Villarreal-Guerrero F, SantellanoEstrada E, Gomez-Simuta Y (2019). Mean lethal dose $\left(\mathrm{LD}_{50}\right)$ and growth reduction $\left(\mathrm{GR}_{50}\right)$ due to gamma radiation in Wilmanlovegrass (Eragrostis superba). Revista Mexicana De CienciasPecuarias10: 227-223.

Ángeles-Espino A, Valencia-Botín AJ, Virgen-Calleros G, Ramírez-Serrano C, Paredes-Gutiérrez L, Hurtado-De la Pena S (2013) Lethal doses $\left(\mathrm{LD}_{50}\right)$ determination using Co60 on Agave tequilana var. Azul vitroplantlets. Revista Fitotecnia Mexicana 36 381-386.

Aparna M, Chaturvedo A, Sreedhar M (2013) Impact of gamma rays on the seed germination and seedling parameters of groundnut (Arachis hypogaeaL.). Asian Journal of Experimental Biological Sciences 4: 61-68.

Chakraborty NR, Kole PC (2008) Biological effects of gamma rays on aromatic rice. Indian Journal of Crop Science 3: 55-58.

Chakraborty NR, Kole PC (2014) Gamma ray induced early generation polygenic variability in medium grain aromatic nonbasmati rice. International Journal of Plant Breeding and Crop Science 1: 28-35.

Chakravarti SK, Kumar H, Lal JP, Vishwakarma MK (2012) Induced mutation in traditional aromatic rice-frequency and spectrum of viable mutations and characterizations of economic values. The Bioscan 7:739-742.

Chandrashekar KR (2014) Gamma sensitivity of forest plants of Western Ghats. Journal of Environmental Radioactivity 132: 100-107.

Cheema AA, Atta BM (2003) Radiosensitivity studies in basmati rice. Pakistan Journal of Botany 35: 197-207.

Duncan DB (1955) Multiple range and multiple $F$ tests. Biometrics 11: 1-42.

Finney DJ (1971) Probit analysis, University Press. Cambridge, UK.

Gaul H (1977) Mutagen effects in the first generation after seed treatment. Manual on Mutation Breeding Technical Reports Series119: 87-98.

Gordon SA (1957) The effects of ionizing radiation on plants: biochemical and physiological aspects. The Quarterly Review of Biology 32: 3-14.
Gowthami R, Vanniarajan C, Souframanien J, Pillai MA (2017) Comparison of radiosensitivity of two rice (Oryza sativa L.) varieties to gamma rays and electron beam in $M_{1}$ generation. Electronic Journal of Plant Breeding 8: 732-741.

Hallajian MT, Ebadi AA, Mohammadi M, Muminjanov H, Jamali SS, Aghamirzaei M (2014) Integration of Mutation and Conventional Breeding Approaches to Develop New Superior Drought-tolerant Plants in Rice (Oryza sativa). Annual Research \& Review in Biology 4(7) 1173-1186.

Hameed K, Sadia B, Habib M, ul Qamar Z, Awan FS (2020) Detection of genetic divergence among Putative Ethyl Methane Sulfonate Mutants of Super Basmati using Microsatellite Marker. DOI: https://doi.org/10.21203/rs.3.rs-34720/v1

Harding SS, Johnson SD, Taylor DR, Dixon CA, Turay MY (2012) Effect of gamma rays on seed germination, seedling height, survival percentage and tiller production in some rice varieties cultivated in Sierra Leone. American Journal of Experimental Agriculture 2: 247-255.

Haris A, Abdullah B, Subaedah A, Jusoff K (2013) Gamma ray radiation mutant rice on local aged dwarf. Middle-East Journal of Scientific Research 15: 1160-1164.

Jan S, Parween T, Siddiqi TO (2012) Anti-oxidant modulation in response to gamma radiation induced oxidative stress in developing seedlings of Psoralea corylifolia L. Journal of Environmental Radioactivity113:142-149.

Joshi B, Gour BK (1974) Comparative study of low and high dose of $\mathrm{x}$ ray irradiation of barley seeds during germination and early growth. In Proceedings of the Symposium-use of radiation and radio isotopes in studies of plant productivity Pp. 187-199.

Khah MA, Verma RC (2015) Assessment of the effects of gamma radiations on various morphological and agronomic traits of common wheat (Triticum aestivum L.) var. WH-147. European Journal of Experimental Biology 5: 6-11.

Khalil SA, Zamir R, Ahmad N (2014) Effect of different propagation techniques and gamma irradiation on major steviol glycoside's content in Stevia rebaudiana. The Journal of Animal \& Plant Sciences 24: 1743-1751.

Khalil SK, Rehman S, Afridi K, Jan MT (1986) Damage induced by gamma radiation in morphological and chemical characteristics of barley. Sarhad Journal of Agriculture 2: 45-52.

Kleinhofs A, Sander C, Nilan RA, Konzak CF (1974) Azide mutagenicity-mechanism and nature of mutants produced. International Atomic Energy Agency (IAEA) 5:195-199. 
Kovacs E, Keresztes A (2002) Effect of gamma and UV-B/C radiation on plant cells. Micron 33: 199-210.

Kumar G, Swati K (2017) Germination and cytological aspects of Dolichos lablab L. exposed to gamma irradiation. Chromosome Botany 12: 63-71.

Kumar V, Vishwakarma G, Chauhan A, Shitre A, Das BK, Nair JP, Surendran P, Sparrow H, Gupta AK (2018) Use of Proton Beam as a Novel Tool for Mutations in Rice. BARC NEWSLETTER 366: 5-9.

Lalitha R, Arunachalam P, Mothilal A, Senthil N, Hemalatha G, Vanniarajan C, Souframanien J (2019) Radiation effect on germination and seedling traits in rice (Oryza sativa L.). Electronic Journal of Plant Breeding 10: 1038-1048.

Li F, Shimizu A, Nishio T, Tsutsumi N, Kato H (2019) Comparison and Characterization of Mutations Induced by Gamma-Ray and Carbon-Ion Irradiation in Rice (Oryza sativa L.) Using Whole-Genome Resequencing. G3: Genes, Genomes, Genetics 9: 3743-3751.

Mamun AN, Kabir MH, Azad AK, Azam MA, Islam MR, Jahan MT, Islam MM, Das P(2020) Development of Rice Mutant Variety with Higher Yield and Improved Agronomic Traits through Carbon Ion Beam Irradiation. In Mutation Breeding Project Forum for Nuclear Cooperation in Asia (FNCA) June 2020: 1-10.

MVD (2020) Mutant variety database. Available on http://mvd.iaea.org/ accessed on 1 April 2020.

Oladosu Y, Rafii MY, Abdullah N, Abdul Malek M, Rahim HA, Hussin G, Abdul Latif M, Kareem I (2014) Genetic variability and selection criteria in rice mutant lines as revealed by quantitative traits. The Scientific World Journal. DOI: https://doi.org/10.1155/2014/190531.

Oladosu Y, Rafii MY, Abdullah N, Hussin G, Ramli A, Rahim HA (2016) Principle and application of plant mutagenesis in crop improvement: a review. Biotechnology \& Biotechnology Equipment 30: 1-16. DOI: 10.1080/13102818.2015.1087333.

Olasupo FO, Ilori CO, Forster BP, Bado S (2016) Mutagenic effects of gamma radiation on eight accessions of Cowpea (Vigna unguiculata [L.] Walp.). American Journal of Plant Sciences 7: 339-351.

Oney-Birol S, Balkan A (2019) Detection of cytogenetic and genotoxic effects of gamma radiation on M-1 generation of three varieties of Triticum aestivum L. Pakistan Journal of Botany 51: 887-894.
Purwanto E, Nandariyah N, Yuwono SS, Yunindanova MB (2019) Induced Mutation for Genetic Improvement in Black Rice Using Gamma-Ray. AGRIVITA, Journal of Agricultural Science 41: 213-220.

Ramchander S, Ushakumari R, Pillai MA (2015) Lethal dose fixation and sensitivity of rice varieties to gamma radiation. Indian Journal of Agricultural Research 49: 24-31.

Rani MH, Kamruzzamana M, Ghanimb AM, Azada MA, Aktera MB (2016) Comparative effect of gamma and X-ray irradiations on some characters of rice seedlings of Ashfal and Binadhan-14. Journal of Bioscience and Agriculture Research8:739-745.

Riley Jr EF (1953) The effects of X-rays upon the growth of Avena seedlings. Abstract No. 48. Radiation Research Society, Iowa City, June: 22-24.

Rutger JN (1992) Impact of mutation breeding in rice- A review. Mutation Breeding Review 8: 1-24.

Sarawgi AK, Soni DK (1993) Induced genetic variability in $\mathrm{M}_{1}$ and $\mathrm{M}_{2}$ population of rice (Oryza sativa $\mathrm{L}$.). Advances in Plant Science 6: 24-33.

Sasikala R, Kalaiyarasi R (2010) Sensitivity of rice varieties to gamma irradiation. Electronic Journal of Plant Breeding 1: 845889.

Spencer-Lopes MM, Forster BP, Jankuloski L (2018) Manual on mutation breeding (No. Ed. 3). Food and Agriculture Organization of the United Nations (FAO).

Thole V, Peraldi A, Worland B, Nicholson P, Doonan JH, Vain P (2012) T-DNA mutagenesis in Brachypodiumdistachyon. Journal of Experimental Botany 63: 567-576.

Ussuf KK, Nair PM (1974) Effect of gamma irradiation on the indole acetic acid synthesizing system and its significance in sprout inhibition of potatoes. Radiation Botany 14: 251-256.

Vasline AY (2013) An investigation on induced mutations in rice (Oryza sativa L.). Plant Archives 13: 555-557.

Wijesena KAK, Nawarathne NMA, Basnayake BMMP (2019) Effect of gamma irradiation on seed germination and plant growth parameters of three rice varietiescultivated in Sri Lanka. Journal of Agriculture and Value Addition 2: 79-84.

Yasmine F, Ullah MA, Ahmad F, Rahman MA, Harun AR (2019) Effects of chronic gamma irradiation on three rice varieties. Journal Sains Nuclear Malaysia 31: 1-10. 